\title{
Stolligaffæren 1936-1940
}

\author{
Af Hans Schultz Hansen
}

Stollig er i dag en mindre landsby, som de fleste haster igennem på vejen mellem Aabenraa og stranden og sommerhusområdet ved Skarrev. De færreste tænker på, at Stollig i anden halvdel af 1930'erne lagde navn til en »affære", der begyndte med en tvangsauktion over en gård og fortsatte med trusler og hærværk mod gårdens nye ejer og endte i et omfattende retsligt opgør mellem ledende nazister i det tyske mindretal og landsdelens justitsmyndigheder. Her redegør Hans Schultz Hansen for Stolligaffæren og dens udløbere. Det sker hovedsagelig på grundlag af domstolenes og politiets akter, der nu er blevet almindeligt tilgængelige.

\section{Stollig - Sønderjyllands urocentrum}

I januar 1938 bragte den ansete Göteborgs Handels- och Sjöfartstidning en længere reportage fra grænselandet. Det skete under overskriften "Stollig - Sönderjyllands oroscentrum«. Til indledning hed det: »I hela Sönderjylland talar man i dessa dagar om blott en enda sak Stollig. Och detta på bägge sidor om den dansk-tyska gränsen. Namnet Stollig är nämligen knutet till sådana händelser och fakta, som i allra högsta grad ha att göra med danskars och tyskars inställning till verandra, icke minst i själva det slesvigska gränslandet.« Avisen citerede føreren for National-Sozialistische Deutsche Arbeiter-Partei Nordschleswig, dyrlæge Jens Møller fra Gråsten, der på et møde i Tønder i december 1937 havde sagt: »Stollig er blevet til et begreb for vor sag «. ${ }^{1}$ Den fremtrædende nazist Chr. Paysen fra Sæd skrev tilsvarende i Nordschleswigsche Zeitung i december 1937: »Stollig er for os blevet vor kamps symbol. Herfra har en betydningsfuld ændring taget sin begyndelse. Stollig er for vor hjemstavn et udtryk for det folkefællesskab, der er blevet til dåd. Stollig er begyndelsen til et nyt kampafsnit i Nordslesvig «. ${ }^{2}$ For landsdelens tysksindede nazister var Stollig således mere end et stednavn: Stollig var en sindstilstand.

På dansk side talte man mere nøgternt om "Stolligaffæren " som en samlebetegnelse for de mange konfrontationer, der udsprang af begivenhederne i landsbyen. ${ }^{3}$ Betegnelsen er siden blevet knæsat af historikerne og vil også blive anvendt her. 
Stolligaffæren vakte enorm opsigt i medierne. Den blev fulgt tæt i grænselandspressen i Nord- og Sydslesvig, men også i de kongerigske aviser og i flere hamborgske blade, mens den øvrige tyske presse, herunder det førende nazistiske organ Völkischer Beobachter, holdt sig til højdepunkterne. De danske repræsentationer i Tyskland sendte indberetninger til Udenrigsministeriet om omtaler af Stolligaffæren i mere end 30 blade. Selv det franske dagblad Le Temps omtalte den. ${ }^{4}$ Især Stolligaffærens halve snes retssager gav stof til pressen. De lagde også stærkt beslag på politiets og domstolenes ressourcer og udviklede sig til et sammenstød mellem den danske retsstats institutioner og de nazistiske ledere inden for mindretallet. På sit højeste førte Stolligaffæren til, at den tyske gesandt i København tog sagen op med den danske regering.

Stollig var således i årene 1936-40 et brændpunkt i striden mellem dansk og tysk. Imidlertid er Stolligaffæren endnu ikke behandlet i sin helhed af historikerne. Peter Fransens undersøgelse er den grundigste og har særligt fokus på politiets indsats. ${ }^{5}$ Sven Tägil og Hilke Lenzing har begge anskuet affæren som et udenrigspolitisk problem i forholdet mellem Danmark og Tyskland. ${ }^{6}$ Selv har jeg beskrevet den ud fra et lokalhistorisk perspektiv. ${ }^{7}$ Den fyldigste omtale er stadig Vilh. la Cours samtidige beretninger i tidsskriftet Grænsevagten.

Sigtet med denne artikel er en dyberegående undersøgelse af Stolligaffæren. Den skal besvare det overordnede spørgsmål: Hvordan kunne det komme så vidt, at en enkelt tvangsauktion fremkaldte så voldsomme reaktioner og vakte så stærk opmærksomhed? Fokus skal især rettes mod fire problemstillinger. Den første er ejerskiftets baggrund i krisen og den nationale jordkamp. Det skal her udredes, hvordan tvangsauktionen forløb og hvorledes de vanlige aktører i den nationale jordkamp handlede. Den anden problemstilling er reaktionen på ejerskiftet med særligt henblik på de metoder, der blev taget $\mathrm{i}$ anvendelse imod den nye ejer af gården. Det tredje undersøgelsesfelt er Stolligaffærens baggrund i nazificeringen af det tyske mindretal og den generelle optrapning af nationalitetskonflikten i perioden. Det fjerde fokus er de danske justitsmyndigheders rolle.

Fremstillingen indledes med et rids af mellemkrigstidens nationale jordkamp, 1930'ernes landbrugskrise, de stridende nazigrupper i det tyske mindretal og de lokale forudsætninger på Løjt Land. Dernæst følges konfliktens forskellige faser. Optakten var den tysksindede gårdejers økonomiske problemer, tvangsauktionen og en dansksindet 
købers overtagelse af gården. Konflikten blev etableret med læserindlæg og en happening vendt mod den nye ejer. Den blev optrappet via anonyme trusselsbreve og graffiti, hærværk og korporlig forulempelse, som politi og retsvæsen reagerede imod. Konflikten blev udvidet med en økonomisk boykot af den nye ejer, og den spredte sig til et politisk og retsligt opgør mellem ledende nazister fra det tyske mindretal og landsdelens danske justitsmyndigheder og presse. Afsluttende gøres kort rede for konfliktens afvikling, og der gives en vurdering af de enkelte aktørers rolle i konflikten.

Kildegrundlaget er i første række domme og politirapporter fra Retten i Aabenraa, Politimesteren i Aabenraa og Politiadjudanten for de sønderjydske Landsdele. Dertil kommer akter fra Udenrigsministeriet, Nordschleswigsche Zeitung, Kreditanstalt Vogelgesang, Landeværnet, Løjt Sparekasse og Stollig Andelsmejeri samt Hans Jefsen Christensens privatarkiv. Materialet er nu almindeligt tilgængeligt. Desuden benyttes centrale udsagn og beretninger fra pressen.

\section{Baggrunden - jordkampen, landbrugskrisen, nazismen og forholdene i Løjt}

Fra 1890'erne var bestræbelser på at sikre mest mulig jord på danskhenholdsvis tysksindede landmænds hænder en integreret del af nationalitetskampen i Sønderjylland. Det var ugleset, at en dansk landmand solgte ejendom til en tysk og vice versa. Jordkampen blev skærpet i september 1926, da Kreditanstalt Vogelgesang blev oprettet. Vogelgesang ydede ikke alene lån til tyske landmænd, men også til nationalt indifferente eller danske, som under landbrugskrisen i midten af 1920'erne var villige til at bekende kulør som tyske til gengæld for et lån. Den danske reaktion kom i januar 1927 med grundlæggelsen af Landeværnet, der alene ydede lån til danske landmænd. ${ }^{8}$

1930/31 ramte den verdensomspændende krise det sønderjyske landbrug. Tvangsauktionerne bredte sig med lynets hast. Fra et lavpunkt på 68 i 1930 steg antallet til 286 i 1931 og 484 i 1932. Sønderjylland var hårdest ramt $\mathrm{i}$ hele landet. Krisebevægelsen Landbrugernes Sammenslutning, kendt som LS, fik i 1931/32 tilslutning fra $70 \%$ af de sønderjyske landmænd. I 1932 stod LS for flere spektakulære aktioner, bl.a. "Stenderupslaget« for at forhindre en tvangsauktion på en gård i Sundeved og »stormen « på Sønderjyllands Kreditforening i Haderslev, men under den moderate gårdejer Peter Nielsen, Refsø, 
blev aktionerne fredeligere, f.eks. en endags mejeristrejke i 1933 og et bondetog til København i 1935. Midt i 1930'erne lysnede forholdene noget for de sønderjyske landmænd. Antallet af tvangsauktioner gik tilbage til 322 i 1933, 379 i 1934 og 181 i 1935. Først derefter kunne krisen siges at være overvundet med 87 tvangsauktioner i 1936 og 84 i 1937.9

Efter Hitlers udnævnelse til tysk rigskansler i januar 1933 greb nazismen brede kredse i det tyske mindretal. Det skete i kølvandet på "påskeblæsten« i foråret 1933, hvor ledende slesvig-holstenske nazister iværksatte en kampagne imod 1920-grænsen. Nazistiske kampmetoder vandt indpas. I første omgang gik de nok så meget ud over de indbyrdes rivaliserende nazistiske grupper. Nationalsozialistische Arbeitsgemeinschaft Nordschleswig, NSAN, opstod i 1933 og fik i 1934 gårdejer Jep Nissen fra Store Jyndevad som »Landesführer«. Heroverfor stod Deutsche National-Sozialistiske Arbeitsgemeinschaft Nordschleswig, DNSAN, under ledelse af fhv. tysk overløjtnant Peter Larsen fra Løjt Skovby (1892-1983). I sommeren 1935 blev de to grupperinger samlet i National-Sozialistische Deutsche Arbeiter-Partei Nordschleswig, NSDAP-N, med dyrlæge Jens Møller (1894-1951) som fører. Men enigheden holdt kun kort, og senere samme år genopstod NSAN. Ved siden af de interne nazistridigheder var der generationsmodsætninger mellem yngre nazistiske aktivister og ældre nationalkonservative mindretalsledere. Først i 1938/39 satte NSDAP-N sig endegyldigt igennem som mindretallets politiske parti med Møller som $\gg$ folkegruppefører ${ }^{10}{ }^{10}$

Udover Peter Larsen var den unge landmand Jep Marcussen Schmidt (1910-88) fra Løjt Kloster en ledende tysksindet nazist på Løjt Land. Under Møllers førerskab blev Larsen partisekretær for NSDAPN, mens Schmidt blev kredsleder på Aabenraaegnen. At Løjt Land fik to mand på ledende poster, var næppe tilfældigt. Mindretallet stod stærkt her, særligt i Stollig med et knebent tysk flertal ved folkeafstemningen i 1920, men også i Barsmark, Høgebjerg og Skovby. Især var tyskheden stærk blandt gårdejerne. I Høgebjerg-Skovby-Stollig var $43 \%$ af jordbesidderne tysksindede, men de ejede $58 \%$ af jorden; i Barsmark-Barsø var tallene tilsvarende. I disse landsbyer slog bondeoverklassen traditionelt tonen an. I 1800-tallet boede Løjts rigeste redere og kaptajner her og gav næring til forestillingen om, at løjtingerne var noget særligt sammenlignet med nabosognenes beboere. I 1930'erne var det fortid, men erindringen levede og styrkedes i 1931 
med Marcus Lauesens succesroman $O g$ nu venter vi paa Skib, der havde storhedstiden og dens udløb som tema. Den stolte fortid satte i særlig grad landbrugskrisen i relief som en social deklassering. På nær én fandt alle 14 tvangsauktioner i Løjt sogn 1927-36 sted i Barsmark, Skovby, Høgebjerg eller Stollig. ${ }^{11}$ Således kom den over 50 ha store Stolliggård, hjemstedet for storhedstidens førende tyske skibsrederfamilie Bendixen, efter en tvangsauktion i 1933 over på danske hænder. ${ }^{12}$

Måske var det ikke tilfældigt, at det sydlige Løjt blev skueplads for det drama, som udspillede sig her og fik navnet Stolligaffæren.

\section{Optakten - tvangsauktionen og dens forhistorie}

I 1824 erhvervede Jes Jørgensen Moos en gård i Stollig, ironisk nok på en tvangsauktion. Efter ham fik sønnen Jørgen Jessen Moos og sønnesønnen Jes Moos gården. Sidstnævntes eneste søn Jørgen Moos faldt i 1916 i Frankrig. I stedet drev enken Clausine Moos gården videre efter mandens død med datteren Mette Alvine Moos, gift Pørksen, som medejer. Dennes søn Thomas Pørksen (1911-83) blev siden antaget som bestyrer, og i 1933 overtog han ejendommen efter sin mor og mormor. ${ }^{13}$ Det skete i forbindelse med en akkord, dvs. en nedskrivning af gælden efter forhandling med kreditorerne. Gårdens areal var da 27 ha. Ved købet overtog Thomas Pørksen en stor gæld: Sønderjyllands Kreditforening 36.000 kr., Sønderjysk Hypotekslånefond 9.000 kr., Løjt Sogns Sparekasse 4.000 kr., Lånekassen for Sønderjylland 5.670 kr. og Erhvervenes Lånefond 32 kr. - i alt 54.702 kr. Desuden skulle Pørksen give Clausine Moos fribolig i to stuer og et køkken i gårdens stuehus. ${ }^{14}$

Unge Pørksen sad hårdt i det. Som tysksindet søgte han naturligt nok Kreditanstalt Vogelgesang om et lån, men både i 1935 og i 1936 fik han afslag. Lederen af Deutsche Wirtschaftsberatungsstelle, dr. Lorenzo Christensen, rådede i april 1936 Pørksen til at lade gården gå på tvangsauktion, men spurgte dog alligevel Vogelgesang. Svaret var et nyt afslag. Risikoen for, at gården ved en tvangsauktion kom på danske hænder, var ringe: »Vi henviser til den af hr. Jep Schmidt fremsatte opfattelse, at man en gang skulle lade tyske gårde falde i danske hænder, for disse vil alligevel ikke vove at sætte den tidligere ejer fra gåden. En sådan fremgangsmåde ville - mente han - også være mere fordelagtig for den tyske kasse. Vi har med henblik på 


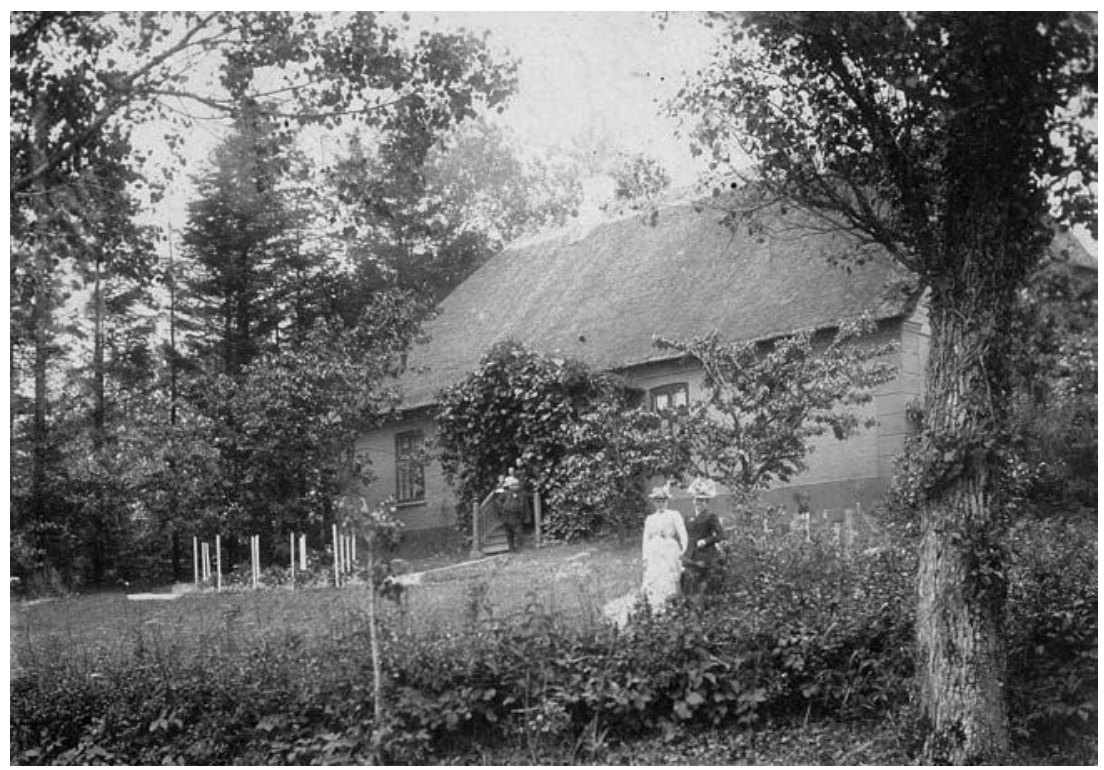

Familien Moos' gård i Stollig, mens alt endnu åndede fred, idyl og velstand før 1914, her set fra haven. Første Verdenskrig kostede imidlertid den udsete arving livet, og $i$ stedet tilfaldt gården i 1933 slægtningen Thomas Pørksen. Da var betingelserne for at drive landbrug radikalt ændret på grund af landbrugskrisen. Foto: Museum Sønderjylland - ISL.

denne, øjensynligt i Løjt ret udbredte mening, allerede forespurgt hos hr. overløjtnant Larsen, om man nu skulle vove eksperimentet med moder Pørksens gård. I tilfældet Thomas Pørksen, som jo i øvrigt alt for tidligt er blevet selvstændig og, som vi hører, ikke kan disponere finansielt, afviser vi altså, for at gentage det endnu engang, enhver stillingtagen før tvangsauktionen. «15

Hverken Vogelgesang eller de førende tyske nazister i Løjt ønskede reelt at hjælpe Pørksen, som man anså for uegnet som selvstændig landmand. ${ }^{16}$ De rådede ham i stedet til at lade gården gå på tvangsauktion, for de troede ikke på, at danske myndigheder turde sætte en tysk landmand ud af sin gård. Det vidner om et overmod, som sikkert beroede på Tysklands genvundne status som stormagt under Hitlers lederskab. Den 7. marts 1936 havde Tyskland besat Rhinlandet.

Med afslaget fra Vogelgesang var Pørksens skæbne beseglet. Sønderjyllands Kreditforening begærede den 17. april 1936 ejendommen sat på tvangsauktion på grund af udeblevne renter og afdrag. Pørksen 
fik udsat auktionen med en ansøgning om sanering, men den blev afvist, og den 2. september blev der holdt auktionsmøde. Tvangsauktionen blev her berammet til den 23. september 1936 på tinghuset $\mathrm{i}$ Aabenraa. ${ }^{17}$

Før tvangsauktionen foregik der et spil om Løjt Sparekasses fordring, som Pørksens mor kautionerede for. Den 3. september holdt sparekassebestyrelsen møde med sin advokat, den dansksindede landsretssagfører Gregers Rosenstand. Her skulle man vælge mellem at overtage ejendommen eller søge fordringen solgt. Et tysksindet bestyrelsesmedlem, gårdejer Hans Nissen Krap, ville gerne erhverve gården til sin svigersøn. Rosenstand fik imidlertid bemyndigelse til at spørge i Hypoteklånefonden, om den kendte til interesserede købere. Senere samme dag meddelte Rosenstand familien Pørksen sparekassens beslutning. Familien havde indstillet sig på tvangsauktionen og anså et godt salg af fordringen for at være i fru Pørksens interesse, da hun så slap fri af sin kautionsforpligtelse. Rosenstand forhandlede herefter med Krap og svigersøn om køb af fordringen, men de afstod. Han telefonerede så til direktør Martin Hammerich fra Hypoteklånefonden - som tillige var formand for Grænsesognenes Danske Samfund. Hammerich havde en mulig køber. Det var gårdejer Mads Warming fra Råhede i Hviding Sogn, som søgte efter en ejendom til sin søn Jørgen og som i forvejen havde en datter boende i Løjt. Ham telefonerede Hammerich til og fortalte, at salget af fordringen skete i forstående med ejeren. Efter at have set ejendommen mødte far og søn Warming den 16. september op på Rosenstands kontor. De bad ham udvirke et skriftligt tilbud fra sparekassen. Den 17. september tilbød sparekassen Warming at købe fordringen for 3.500 kr. Den 18. september meldte Krap, at han og svigersønnen alligevel ville byde 3.000, om nødvendigt $3.500 \mathrm{kr}$. for sparekassens fordring. Den 19. september erklærede Warming, at han antog sparekassens tilbud. På et møde med sparekassen den 21. september kom købet i stand. Warming stod nu stærkt som køber ved tvangsauktionen. ${ }^{18}$

Ligeledes inden tvangsauktionen anmodede hr. Witt fra Stollig Vogelgesang om hjælp til at købe ejendommen, men skønt tysksindet blev han afvist med den begrundelse, at kreditanstalten ikke ville »jage en tysker fra gården til fordel for en anden «. ${ }^{19}$ Kreditanstaltens tillidsmand, Jürgen Schmidt fra Øster Terp, berettede ellers efter en forhandling med fru Pørksen, at »tilfældet er håbløst« og en tvangsauktion uundgåelig. ${ }^{20}$ 
Den 23. september 1936 fandt tvangsauktionen sted. ${ }^{21}$ Først blev gården sat på auktion på det vilkår, at Clausine Moos kunne blive boende. Der fremkom ingen bud. Dernæst blev der holdt auktion uden bolig for fru Moos. Der fremkom nu to bud: Overretssagfører Holger Boeck 100 kr. på vegne af Sønderjyllands Kreditforening og landsretssagfører Rosenstand 49.600 kr. på vegne af Jørgen Warming. Imidlertid begærede Thomas Pørksen auktionen udsat, da Nis Lorenz Closter fra Stollig ville forsøge at redde ejendommen for familien. Den blev derfor udskudt til den 10. oktober. Rosenstand forhøjede Warmings bud til $53.450 \mathrm{kr}$.

Da det blev klart for de tysksindede i Løjt, at en dansksindet køber stod parat, blev det fem minutter i tolv forsøgt at holde Pørksen ved gården. Fru Pørksen, Nis Lorenz Closter fra Stollig og gårdejer Christian Matthiesen fra Fladsten opsøgte Mads Warming for at få ham til at trække sit bud tilbage, så fru Pørksen kunne overtage gården og drive den sammen med sin egen. Mads Warming anså dette for urealistisk og afviste. ${ }^{22}$ Til politiet fortalte han senere, at hverken han selv eller sønnen ville medvirke til at bevare ejendommen på tyske hænder. ${ }^{23}$ Mads Warming kom fra en udpræget dansksindet familie. Hans far var dansk statsborger og blev udvist af de preussiske myndigheder. I 1904 forsøgte den unge Mads at befri sin far, da denne under et illegalt besøg i hjemmet blev pågrebet af en hjemmetysk husmand, hvilket indbragte ham en bøde på 100 mark. ${ }^{24}$ Ifølge Martin Hammerich besad Warming senior »Vestboens stædighed «. ${ }^{25}$

Ifølge redningsplanen skulle fru Pørksen overtage gården på tvangsauktionen. 30 tønder land skulle bortforpagtes til Matthiesen. De tilbageværende 24 tønder land skulle Thomas Pørksen forpagte. Fru Moos skulle blive boende på gården og af sin invaliderente betale husleje og føre huset, så lønnen til en pige kunne spares. Til at overvåge driften og rådgive Pørksen skulle der indsættes et »kuratorium« med tre erfarne landmænd, heriblandt Matthiesen som repræsentant for Vogelgesang. Oven i nogle privat fremskaffede midler skulle der bruges et lån hos Kreditanstalten på knap 3.500 kr. Den 9. oktober blev planen forelagt skibsreder Jacob Jebsen i Aabenraa, som videresendte den til Vogelgesang samme dag. Skibsrederen indså, at planen var »temmelig udsigtsløs« og bemærkede: »Skylden for dette bærer naturligvis i det væsentligste hans rådgivere (hr. Larsen) og hetzen imod Deres institut, som sluttelig fører dertil, at folkene ikke tror på hjælp hos Dem. Jeg vil imidlertid ikke undlade at videregive de ved- 
Mads Warming (1876-1964) var gårdejer $i$ Råhede $i$ Hviding sogn og søgte efter en gård til sin søn Jørgen. Han kom fra en udpræget dansksindet familie og havde som ung været $i$ konflikt med de preussiske myndigheder. Da han forst havde sat sig for at erhverve gården $i$ Stollig på tvangsauktionen, lod han sig ikke bevæge fra sit fortsæt, og han bød derfor højst og fik ejendommen. Foto i privateje.

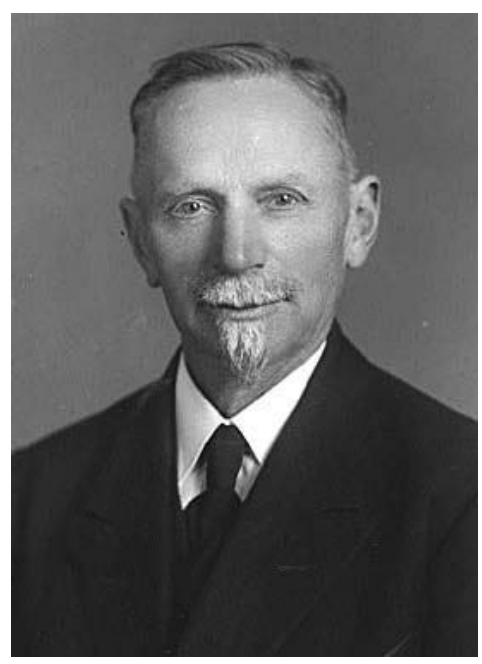

lagte enkeltheder til dem. De ved, at jeg altid har haft en interesse for halvøen Løjt, hvis tyskhed jo er helt særligt truet. Lykkes det Hammerich at få gården eller en del af jorden over på sin hånd, vil der naturligvis opstå nye bosættelser. «26 Jebsen nærede tydeligvis mere sympati for den nationalkonservative Georg Vogelgesang end for den nazistiske Peter Larsen.

Samme dag mødte Hans Krag, Jep Schmidt og Nis Lorenz Closter op hos Vogelgesang med planen; dog blev lånebehovet nu sat til 9.883 kr. Vogelgesang gav grønt lys med den begrundelse: »at det drejer sig om en gammel familieejendom, at hr. Jepsen [!], Aabenraa, er gået ind for den og at de tre herrer [Mathiesen, Closter og en tredje] vil stå inde for en ordentlig drift «. ${ }^{27}$

Den 10. oktober 1936 fandt anden tvangsauktion sted. ${ }^{28}$ Landsretssagfører Weber bød 53.550 kr. på vegne af fru Moos. Han begærede auktionen suspenderet og ringede op til Vogelgesang, der bekræftede, at kreditanstalten stod inde for fru Moos. ${ }^{29}$ Landsretssagfører Rosenstand bød derefter over med 100 kr. Sådan fortsatte de to advokater, indtil Rosenstand nåede op på 54.500 kr. Han begærede da, at Weber skulle stille yderligere sikkerhed. Det blev afvist af fogeden. Rosenstand bød da 55.000 kr. og oplyste, at han bød på vegne af Jørgen Warming, samt at denne siden første auktion havde erhvervet Lånekassen for Sønderjyllands fordring. Da Lånekassen sad i femte prioritet, var denne fordring reelt værdiløs, og Warming havde derfor købt 
den første fordring på $1.182 \mathrm{kr}$. for $100 \mathrm{kr} .{ }^{30}$ Med sit sidste bud havde Rosenstand budt 50 kr. ind i Lånekassens - nu Warmings - fordring, der dog dermed langtfra var dækket ind. Derfor erklærede Rosenstand, at han, såfremt overbud ikke fremkom, ville begære auktionen standset for at Warming kunne overtage ejendommen som ufyldestgjort panthaver, dvs. som en kreditor, der ikke kunne få sin fordring dækket fuldt ind ved det sidste bud. Der kom ikke flere bud. Alligevel gav Rosenstand Weber en sidste mulighed for at byde, såfremt han kunne stille sikkerhed for $10.000 \mathrm{kr}$. til dækning af restancer, omkostninger og Warmings tilgodehavender. Auktionen blev udsat i en halv time for at give Weber lejlighed til dette. Det var imidlertid ikke muligt - efter sigende, fordi Vogelgesang afviste videre medvirken. Weber begærede auktionen udsat i 8 dage, men det havde fogeden ikke hjemmel til. Auktionen blev derfor standset, og ejendommen tilfaldt Jørgen Warming.

Ansvaret for dette udfald lå på tysk side. Man afviste at hjælpe Pørksen og satsede overmodigt på, at danske myndigheder ikke turde sætte ham ud ved tvangsauktionen. Man forspildte to chancer for at søge gården solgt til andre tysksindede landmænd. Der manglede fodslag mellem de lokale tyske ledere, de tysksindede medlemmer af sparekassens bestyrelse og kreditanstalten. Da man fik en redningsplan i stand, var tidspunktet forpasset. Den danske side var anderledes effektiv. Da sparekassen satte sin fordring til salg, fandt man en dansksindet køber. Mads Warming købte den i tiltro til, at Pørksens havde opgivet at beholde ejendommen, men fastholdt sin interesse i gården på trods af redningsplanen, fordi denne i sit sigte var tysk. Jørgen Warming fik hurtig hjælp til overtagelsen. Landeværnets næstformand Hans Jefsen Christensen og direktør i Sønderjyllands Kreditforening P.A. Callø sørgede for et lån til ham på $3.000 \mathrm{kr}$. fra skibsreder A.P. Møller, der støttede danske landmænd i jordkampen. Det skete med begrundelsen: „Gården er meget forsømt, men kommer nu i en dygtig ung mands hænder«. Landeværnet gav et lån på 2.200 kr. for at »få denne ejendom på danske hænder «, ligesom Hypoteklånefonden gav afkald på 1.600 kr. i restancer og Lånekassen ydede et lån på $4.700 \mathrm{kr}$. Mads Warming selv kom til at betale 12-13.000 kr. ${ }^{31}$ De ledende skikkelser i landsdelens danske jord- og nationalpolitiske miljø greb således den opståede mulighed for at svække hjemmetyskheden i Stollig.

Warmings overtagelse af Pørksens ejendom var dermed en del af den standende jordkamp, hvor ejendomme gik fra tysk over i dansk 
eje eller omvendt - det sidste forekom også. ${ }^{32}$ Set i dette lys overrasker det, at reaktionen på netop dette ejerskifte blev så voldsom.

\section{Konflikten begynder - Jep Schmidts læserbreve og "genindsættelse« af Pørksen}

Udfaldet af tvangsauktionen fik, den 20. oktober 1936, Jep Schmidt til at skrive et læserbrev i Nordschleswigsche Zeitung med overskriften »Afskyelig klapjagt på ældgammel tysk arvegård «. Her blev det fremstillet således, at familien Moos havde siddet på gården siden de brutale svenskekrige i midten af 1600-tallet, hvortil Schmidt føjede: »1011 generationer efter Trediveårskrigens skræk falder den marxistiske stats hammer over ejendommen. Hvad der var uadskilleligt i fire lange århundreder, trods mord og krig, inflation og misvækst, det bliver i dag splittet ad og slået i stykker i det »frie« demokratiske Danmark." Med tydelig inspiration fra nazistisk Blut und Boden ideologi hed det videre: »Bonde og hjemstavn, familie og arvegård, de hørte sammen på grund af Trediveårskrigens blodoffer, i kraft af sved og arbejde gennem lange århundreder en enhed.«

Efter tysk Blut und Boden tankegang var bonden og jorden uadskillelige. Bønderne udgjorde samfundets rygrad, der skulle sikre fornyelsen af det tyske folks blod. Tvangsauktioner var derfor utænkelige og blev standset af nazistyret med den såkaldte "rigsarvegårdslov « fra 1933, der sikrede gården i slægtens besiddelse. Med disse gennemgående tågede, antimoderne forestillinger lykkedes det nazisterne at vinde stærk opbakning i den tyske landbefolkning, særlig på højderyggen i Sydslesvig. Jep Schmidt forsøgte helt indlysende at overføre denne succes til Nordslesvig.

Ifølge Schmidt viste tvangsauktionen »med hvilke brutale midler tvangsdaniseringen af vores nordslesvigske hjemstavn bliver gennemført. Statens forenede pengeinstitutter har bevist, at de ikke kender til ligeberettigelse. De forfølger planmæssigt deres mål, tro mod marxismens og den aggressive grænsedanskheds grundsætninger, at smadre den nordslesvigske og frem for alt den hjemmetyske bondestand. « Jep Schmidt rettede også sin vrede mod Warming personligt: »Træffende for karakteristikken af den nye ejer, hr. Warming, er de ord, som han slyngede imod den 70-årige fru Moos, da hun bad ham om at afstå fra købet af hendes slægtsgård. »Jeg har den samme ret til gården som Dem«, sådan lød hr. Warmings svar. Vi ved altså, hvem 
vi har at gøre med«. Meget betegnende sluttede læserbrevet med et »Heil Hitler! «. ${ }^{33}$

Mads Warming bestred, at han selv eller sønnen skulle have sagt som citeret til fru Moos. ${ }^{34}$ Også nøjagtigheden i slægts- og ejendomshistorien var det så som så med. Som nævnt kom familien Moos først i besiddelse af gården i 1824 ved en tvangsauktion. Eller også blev sådanne detaljer underordnet det politiske formål. I øvrigt blev det i november 1937 påvist, at Jep Schmidts egen oldefar i 1822 havde erhvervet gården i Løjt Kloster på en tvangsauktion. ${ }^{35}$

Jep Schmidt skrev også om tvangsauktionen til gårdejer Wilhelm Deichgräbers blad Nordslesvig venter. Her spandt han videre på Blut und Boden tråden og skrev blandt andet: "Systemets sejr synes at være fuldstændig - hvis ikke - ja, hvis ikke vi lever i en tid, hvor retsopfattelsen er ved at blive revideret. En tid, hvor nye tanker vinder frem, og den evige lov om blod og jord på ny bliver ret. Hvor vor nuværende romerske retskendelse bliver afløst af germanernes love, og hvor gamle slægter bliver sat ind i deres gamle rettigheder «. Håbet var altså, at nazismen snart også brød igennem i Danmark. Truende mod Jørgen Warming hed det videre: »For de folk, der som hyæner i disse brydningsår har benyttet sig af deres næstes nød, har vi kun ét tilovers: I bliver husket og aldrig glemt «. ${ }^{36}$

Jep Schmidt iværksatte også en happening, hvormed han "genindsatte« Pørksen som ejer af gården. Jørgen Warming flyttede ind på gården den 15. oktober 1936, mens Pørksen fik lov til at blive boende til den 19. samme måned, hvor han flyttede ud med sine sidste ting. Den 20. oktober ved 19.30-tiden kom der imidlertid en lastbil ind på gårdspladsen. Med den kørte Thomas Pørksen, Walter Spies fra Barsmark og Jep Schmidt fra Løjt Kloster. På ladet befandt sig Thomas Pørksens seng med sengetøj, et par gamle stole og et gammelt bord. Trods Jørgen Warmings protester blev møblementet læsset af og sat ind i gårdens forstue. Schmidt og Spies kørte igen, mens Pørksen slog sig ned i forstuen. Da han nægtede at forlade ejendommen, tilkaldte Jørgen Warming politiet. Det skete ved ottetiden. Politiet kom og gav Pørksen ordre til staks at forlade ejendommen og afhente sine møbler næste morgen. Pørksen forlod derefter gården ved nitiden. Derimod hentede han ikke sine ejendele den næste dag, og Warming stillede dem derfor ud i gårdens lade. Den 22. oktober kørte han dem ind til tinghuset i Aabenraa, hvor de blev optaget som hittegods. Først den 2. november hentede Pørksen sit habengut hos retten. Warming øn- 
skede intet yderligere foretaget. Et modtaget trusselsbrev anså han for en drengestreg eller en dårlig spøg. ${ }^{37}$ Denne moderate holdning høstede han kun utak for.

Jep Schmidts aktion vakte stor opsigt i aviserne. Nordschleswigsche Zeitung overdramatiserede politiets bortvisning af Pørksen med påstanden: "Den fra sin arvegård fordrevne bonde Thomas Pørksen-Stollig blev i går aftes sat ud i natten af to politibetjente «. ${ }^{38}$ Nis Lorenz Closter skildrede i et læserbrev årsagen til »genindsættelsen «: »Hjemve efter sine fædres gamle arvegård, mindet om hans i krigen for fædrelandet faldne onkel, hvis arv han havde tiltrådt, har ikke ladet ham i ro, og til sidst foranledigede hans tro hunds tiggeri ham til at flytte ind i sit hus med nogle få ejendele.« Closter mindede Warming om det 9. bud: »Du må ikke begære din næstes hus«. Han så frelsen i nazismen: »Dog nationalsocialismens flodbølge vil også skylle over til os, lige så sikkert som Reformationen for 400 år siden. Heil Hitler «. ${ }^{39}$ De følgende dage bragte avisen en lang reportage om forløbet af tvangsauktionen, der blev betegnet som en »brutal voldtægt af en bofast hjemmetysk familie« med den hensigt: »Man ville fortrænge familien Moos-Pørksen fra deres gård, fordi de er tyske! « ${ }^{40}$ Tonelejet var skingert og skabte et klima, hvor yderligtgående aktioner kunne forudses.

De danske aviser tog som ventet afstand fra Jep Schmidts aktion. ${ }^{41}$ Heller ikke alle i mindretallet billigede den. Folketingsmand Johannes Schmidt betegnede i et brev til Vogelgesang Jep Schmidts aktion som »en dumhed, som man ikke kan holde hånden over«. Vogelgesang selv skrev i et brev til bankdirektør Karl Orth i Flensborg: »Desværre synes man fra ung tysk side at tilføje Warming, der allerede er flyttet ind på ejendommen, allehånde slags terror og drengestreger. Det svarer til den som følge af en forbryderisk agitation sig stadig mere udbredende tøjlesløshed «. Man får her et glimt af den nationalkonservative Vogelgesangs afstandtagen til nazismen eller i det mindste til dens frembrusende repræsentanter. ${ }^{42}$

Jørgen og Mads Warming anmeldte til politiet, at Thomas Pørksen efter deres mening uretmæssigt havde solgt korn fra gården mellem de to tvangsauktioner. Da de beså gården et par dage før den første auktion, bemærkede de utærsket korn i laden, som manglede efter den anden auktion. De anslog, at der var fjernet ca. 150 tønder korn. Foreholdt dette bragte Pørksen ca. 50 tønder tilbage. Warming var ikke tilfreds, men bad politiet om ikke at foretage sig videre. ${ }^{43}$ Havde han håbet dermed at bringe sindene til ro, tog han fejl. 


\section{Konflikten tilspidses - trusselbreve, graffiti og hærværk}

Det varede ikke længe, før der også blev grebet til kriminelle handlinger imod Jørgen Warming for at fordrive ham fra gården. ${ }^{44}$

Den 15. oktober 1936 modtog Jørgen Warming et anonymt brev med teksten: »Kender du det tiende bud? Hved du at du er en elendig røver en grådig sjakal. Du har bevist at du ikke kender barmhjertighed. Vær sikker på, at du ej heller skal få pardon, når vi gør regnskabet op! Du skal ikke blive glemt«. Det tiende bud lød efter Luthers lille katekismus: »Du må ikke begære din næstes hustru, folk eller fæ eller noget, der hører din næste til «. ${ }^{45}$ Den 21.-22. oktober 1936 fik Jørgen Warming anonymt tilsendt et eksemplar af Luthers lille katekismus, hvor det 9. bud var indstreget med rødt. Det lyder: »Du må ikke begære din næstes hus «. ${ }^{46}$ De anonyme henvendelser sigtede således både til den faste ejendom og løsøret!

En nat omkring den 31. oktober 1936 blev der slået fire ruder ind i gårdens stuehus, heriblandt to i soveværelset. En gang i oktober forsøgte nogen at overtale Jørgen Warmings tjenestekarl Johan Alfred Svenson til at lægge et stykke jern i Warmings hakkelsesmaskine, så den ville gå i stykker, når den blev sat i gang. En nat 1-2 uger før jul 1936 blev der på gavlen af Stollig mejeri ud mod vejen malet med hvid oliemaling: »Warming kæltring «, men mejeribestyrer Asmus Hende vaskede det væk. Julenat 1936 gentog begge dele sig. Natten til den 12. januar 1937 blev der slået 13 ruder ind i gårdens stuehus og ødelagt fem vinduesrammer og sprosser. Igen gik det ud over soveværelset, hvor Jørgen Warming denne gang lå og sov. Desuden blev der hældt to dunke med petroleum og en sæk med hestemøg i gårdens brønd, som derved blev gjort ubrugelig i længere tid. Brønden lå ca. 200 meter nordøst for gården. Samme nat blev der på Stolliggårds mur ud mod vejen med røde bogstaver malet »Tyv Warming «.

Sådanne metoder var sjældne i den dansk-tyske nationalitetskamp og vakte derfor opsigt i pressen. Nordschleswigsche Zeitung bestred, at tysksindede stod bag. Imidlertid blev metoderne mødt med forståelse af overløjtnant Peter Larsen, Skovby, der i Hejmdal kommenterede avisens afstandtagen fra dem således: »Hejmdal kan i øvrigt godt forskåne os for sådanne ramaskrig. Den nordslesvigske bonde, der kæmper en fortvivlet kamp, er aldeles ikke betænkelig ved de metoder, der er bleven anvendt overfor J. Warming, Stollig. Han er tværtimod overbe- 


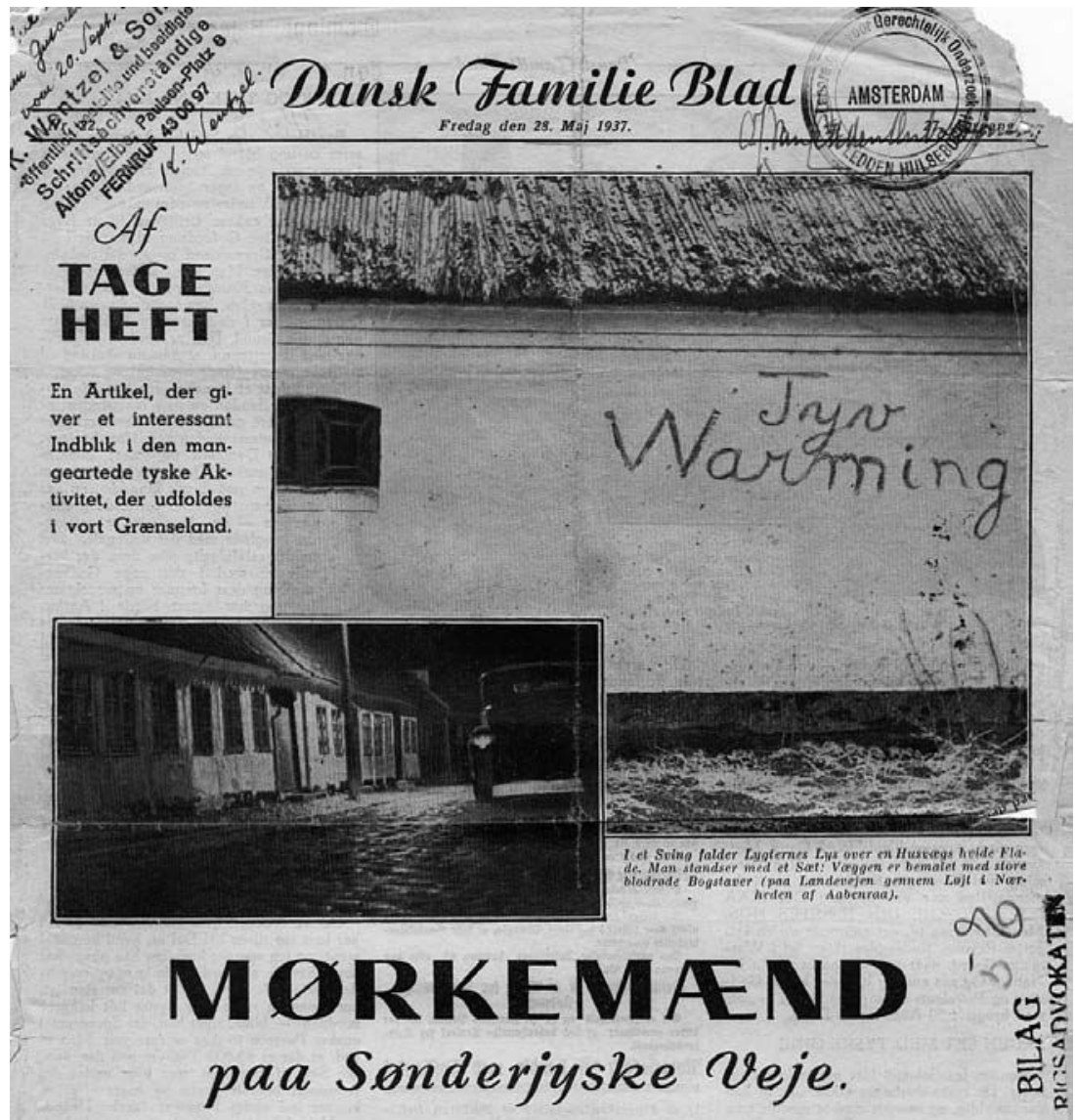

Graffiti på Stolliggårds mure vendt mod Jørgen Warming. Fra reportage $i$ »Dansk Familieblad " maj 1937, som indgik i retssagen. RAA, Aabenraa politi nr. 280: Straffeakt 1/1947.

vist om, at kun anvendelsen af disse metoder vil bidrage til at skabe andre forhold. Denne lille ubetydelige episode er måske kun indledningen til langt alvorligere tildragelser. Men når allerede denne kan bidrage til at folk som Warming, Råhede, bliver betænkelig ved på en sådan måde at udnytte en standsfælles nødstilstand og fremtidig ser bort fra at strække deres begærlige fingre ud efter vor hjemlige jord, så er efter min opfattelse hensigten nået. « ${ }^{47}$ Peter Larsen var som partisekretær for NSDAP-N en fremtrædende mand i mindretallet. Derfor kan hans udtalelse vanskeligt tolkes anderledes, end at man her 
på højeste sted accepterede metoderne. Dette omfattede dog ikke pastor Schmidt, der i Folketinget den 4. maj 1937 udtalte: »Selvfølgelig fordømmer jeg den fremgangsmåde, der er brugt, også hvis det virkelig var gjort fra tysk side, hvad der jo ikke er eftervist. « ${ }^{48}$

Politiet iværksatte en omfattende efterforskning for at finde de skyldige. I flere henseender fik den et vanskeligt og problematisk forløb. Vanskeligt, fordi politiet ofte stødte mod en mur af tavshed i lokalbefolkningen. Problematisk, fordi nogle politifolk viste modvilje mod Jørgen Warming, mens andre var for tjenstivrige. Da Warming anmeldte rudeknusningen, sagde overbetjent Larsen: »Ja, Warming jo oftere De løber til politiet des værre bliver det«, og han opfordrede i stedet Warming til at anskaffe sig et jagtgevær og en bidsk hund. En anden sagde: »Warming, når man har fået en ejendom, må man også være mand for at værge den«. En tredje betjent ville ikke tage Warmings anmeldelse af det ovennævnte ulovlige kornsalg alvorligt. ${ }^{49}$ Omvendt fremgår det af politiets egen rapport, at kriminalbetjent Jørgen Nielsen fremkom »i den vanskelige sags interesse med en udtalelse om, at hvis han [ovennævnte tjenestekarl Svenson] kunne komme med positive oplysninger, skulle det ikke skorte på en belønning, og han sagde videre, at han (Nielsen) ikke var uvillig til at betale ham en »hundredelap « af egen lomme. Svenson ville gerne tjene en sådan skilling. « ${ }^{50}$ Kriminalbetjenten var altså så ivrigt efter at skaffe beviser til veje, at han ville købe sig til et vidneudsagn hos en fattig landarbejder, en metode, som man skulle tro mere hørte hjemme i en amerikansk film end i en dansk kriminalsag.

Politiets efterforskning førte til, at Jep Schmidt blev anholdt den 23. februar 1937 og Thomas Pørksen den 27. De blev begge sat under tiltale for hærværk og for ærekrænkelse og blev fængslet indtil henholdsvis den 5. og den 10. marts. De nægtede begge at have begået eller medvirket til forbrydelserne. Endvidere blev Nis Lorenz Closter sat under tiltale, men alene for ærekrænkelse, og derfor ikke fængslet. Også han nægtede sig skyldig.

Fængslingen af Jep Schmidt vakte stor opsigt. De tysksindede på Løjt Land holdt den 25. februar opstillingsmøde til sognerådsvalget i Løjt Kirkeby. Deltagerne, hvis antal blev opgivet forskelligt i pressen til mellem 100 og 300, opstillede Jep Schmidt som spidskandidat på Schleswigscher Wählervereins liste. Det var et klart tillidsvotum. Der blev også vedtaget en længere resolution mod fængslingen af Jep Schmidt, som sluttede således: »Vi vil være fri for tvangsauktioner, 


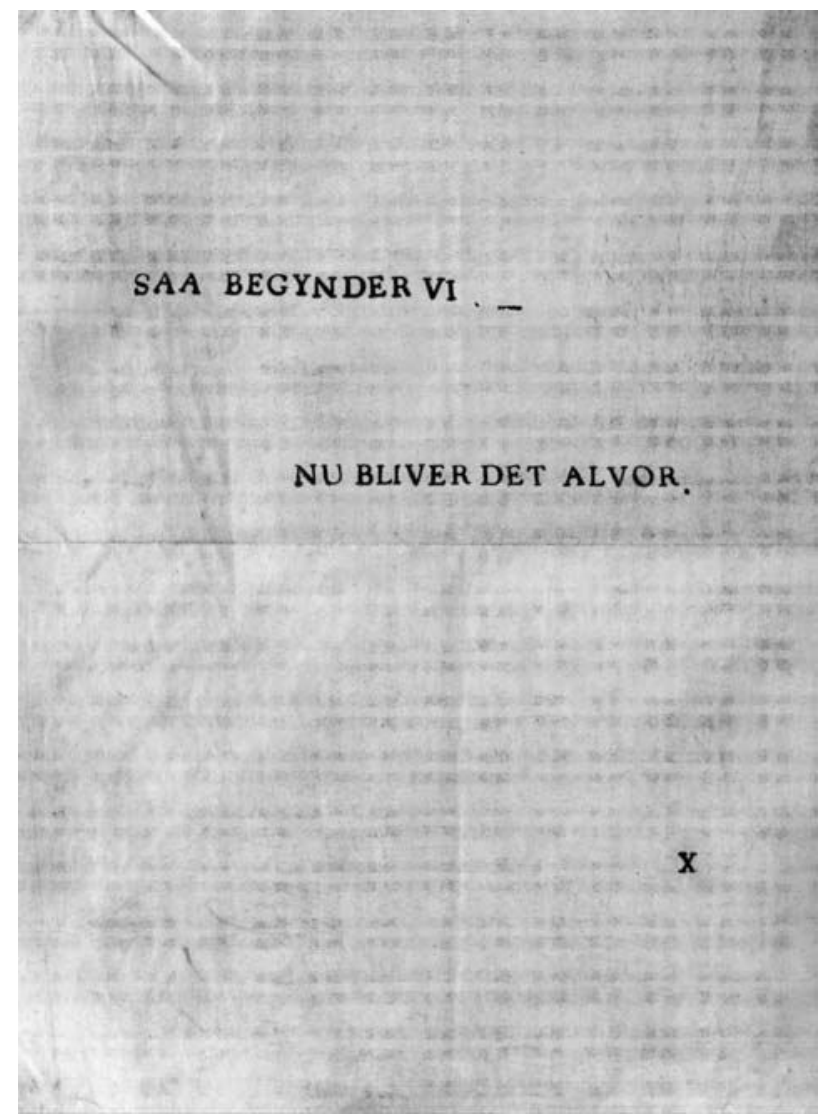

Et af de anonyme trusselsbreve sendt $i$ begyndelsen af maj 1937 til Jørgen Warming, Stollig. RAÅ, Aabenraa politi nr. 280, straffeakt 1/1947.

akkord, udsættelser og deslige. Og vi ønsker, at vore egne folk ikke udsættes for politiets forfølgelser, fordi de kæmper for bondestandens befrielse.« Resolutionen var temmelig moderat uden nazistiske markeringer. En til lejligheden digtet sang blev sunget. Den rummede blandt andet følgende løfte til Warming: »For folk som dig er der ingen plads her, det vil vi bevidne«. Ved halvettiden om natten gik mødedeltagerne $\mathrm{i}$ tavs protestmarch forbi Warmings gård. Blandt de marcherende var Jens Møller, Deichgräber, Closter og Larsen. Da marchdeltagerne nåede frem til gården, hvor politiet var kommet til stede, trampede de demonstrativt taktfast i vejbelægningen. Ved halvtotiden blev marchen opløst, og deltagerne søgte hjemefter. ${ }^{51}$ 
Mens politiet og retten arbejdede, fortsatte chikanerne mod Warming. Den 28. april 1937 anmeldte han, at der var fjernet tandhjul og skruenøgler fra hans såmaskine, mens den stod ude på marken. Den 4. maj modtog han et nyt trusselsbrev med den håndtrykte tekst: „Så begynder vi. Nu bliver det alvor«. Og endelig blev i anden halvdel af juni et elektrisk kabel hørende til hans motor i laden skåret over to steder. Det lykkedes ikke politiet at finde gerningsmændene til disse forbrydelser. ${ }^{52}$

\section{Stolligsagen for retten}

Den 12. maj 1937 begyndte sagen mod Jep Schmidt, Thomas Pørksen og Nis Lorenz Closter ved Retten i Aabenraa. Politimester Aage Agersted var anklager. Jep Schmidt holdt en forsvarstale, som viste, at han havde lært af sit store forbillede Adolf Hitler, der efter sit fejlslagne ølstuekup i München i 1923 misbrugte retssalen som politisk talerstol. Schmidt betegnede anklagerne imod ham som »det uhyrligste m.h.t. fantasi og fri digtning «. Idet han uden videre tog alle landsdelens bønder til indtægt for sine synspunkter, hævdede han: »Det er ikke Nordslesvigs bønder, som hører til på anklagebænken, men det danske system «. Han citerede »vor fører « for at sige: »Glem ikke, at den helligste ret på jorden er bondens ret til sin ager, til sit hjems muld, som han og generationer før ham med stor flid har drevet og dyrket", ligesom han slog fast: "Skal jeg have et moralsk ansvar, så må jeg give dette videre til den, der har givet den nordslesvigske bonde en ny frihedsvilje, til Adolf Hitler. « ${ }^{53}$

Den 19. maj blev der fældet dom. ${ }^{54}$ Schmidt fik 10 dages hæfte, dvs. en mildere form for indespærring uden for det egentlige fængsel og med mulighed for egen forplejning og eget arbejde. Straffen blev anset for udstået med varetægtsfængslingen. Retten fandt det ikke bevist, at han havde deltaget i hærværket mod Warming. Derimod anså retten det for godtgjort, at han havde skrevet det anonyme brev, som Warming modtog den 15. oktober 1936. En indkaldt skriftekspert havde erklæret, at skriften i brevet efter alt at dømme var identisk med Schmidts håndskrift. Retten fandt, at brevet både var ærekrænkende og rummede en trussel mod Warming.

Thomas Pørksen fik otte måneders fængsel og blev frakendt de borgerlige rettigheder i fem år. En række indicier pegede på ham. For det første var han forbitret over Warmings køb af gården på tvangs- 
auktionen og viste sig aggressiv ved at have anstiftet sin egen "genindsættelse«. For det andet vidste han ifølge vidneudsagn fra Jørgen Warming, i hvilket værelse denne sov. For det tredje vidste han, at der ved de ituslåede vinduer befandt sig en kældernedgang, som ikkestedkendte nemt kunne falde ned i. For det fjerde kendte han til placeringen af brønden, skønt den lå afsides og skjult i forhold til gården. For det femte havde han dagen før brøndforgiftningen til brug for Nis Lorenz Closter købt 40 liter motorpetroleum hos købmand Struckmann i Bodum, og Teknologisk Institut havde fundet frem til, at der netop var hældt motorpetroleum i brønden. For det sjette måtte en høj person stå bag skriveriet på Stolliggårds mure, og Pørksen var netop over middelhøjde. For det syvende blev en åben dåse med rød mønje af samme type som den, der var benyttet ved smædeskriveriet, fundet på Pørksens mors ejendom, hvor han opholdt sig. For det ottende erklærede arbejdsmand Svenson, der først havde arbejdet for Pørksen og siden for Warming, at førstnævnte havde forsøgt at overtale ham til at jage et stykke jern i Warmings hakkelsesmaskine. Som nævnt var Svenson dog næppe noget pålideligt vidne.

Nis Lorenz Closter blev idømt en bøde på 100 kr., subsidiært hæfte i fire dage. Han erkendte at have sendt katekismen med det 9. bud understreget med rødt til Warming uden afsenderadresse, men ikke, at det skulle være ærekrænkende.

Ud over straffedommene skulle de tre betale erstatninger for lidelser, tort og ulempe til Warming: Closter 50 kr., Schmidt 100 kr. og Pørksen 500 kr.

Dommen vakte stærk opsigt i pressen. Holdningen til dem afspejlede ganske forudsigeligt de nationale skillelinjer. ${ }^{55}$ Jens Møller betegnede den 21. maj 1937 i et opråb til sine meningsfæller i NSDAP-N kendelsen fra retten i Aabenraa som »en skændselsdom «, der afspejlede systemets forfølgelse af nationalsocialisterne. ${ }^{56}$

De tre dømte appellerede deres domme til Vestre Landsret. ${ }^{57}$ Statsadvokat Holm krævede Jep Schmidt dømt i overensstemmelse med det oprindelige anklageskrift, altså også for hærværk, og ønskede i øvrigt dommene stadfæstet, men med højere straffe. Landsretssagførerne Weber og Clausen krævede alle tre frifundet. Den 27. juli 1937 afsagde landsretten sin dom. Den frifandt Jep Schmidt ikke alene for hærværket, men også for at have sendt det anonyme brev til Jørgen Warming, da der ikke var ført tilstrækkeligt bevis herfor. Derimod blev dommene over Pørksen og Closter stadfæstet. ${ }^{58}$ Den nye dom 


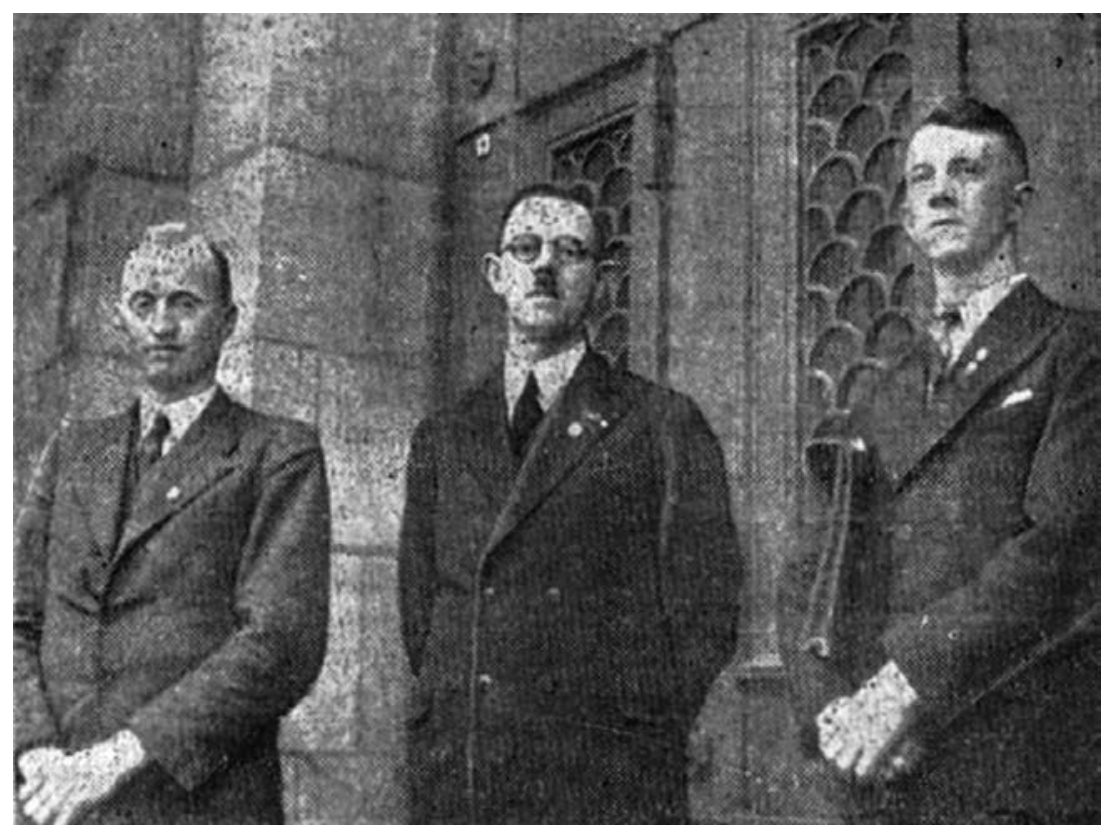

De tre anklagede i Stolligsagen for Højesteret. Fra venstre Thomas Pørksen, Lorenz Closter og Jep Schmidt. Efter Hejmdal 15. februar 1938.

vakte endnu større opsigt i pressen. Nordschleswigsche Zeitung betegnede den som en $»$ fejldom $« .59$

Pørksen søgte om at få sin sag prøvet for Højesteret, og det blev bevilget. Anklagemyndigheden indankede dommene over både Pørksen og Schmidt. Det sidste var næppe taktisk klogt, da retssagen derved fik en stærkere politisk karakter. Den 18. februar 1938 fandt Højesteret frem til sin afgørelse. Ikke alene Jep Schmidt, men også Thomas Pørksen blev nu frifundet. Højesteret fandt, at uviljen mod Warmings køb af gården var ret udbredt i lokalområdet, og at der savnedes tilstrækkelig sikkerhed for, at netop Schmidt og Pørksen skulle have begået forbrydelserne. Specielt om Svensons vidneudsagn fandt Højesteret, at det var usikkert, hvorvidt Pørksens ord til Svenson om at lægge jern i hakkelsesmaskinen havde karakter af en strafbar opfordring. Højesteret afviste dog de to tiltaltes krav om erstatning for uberettiget fængsling. ${ }^{60}$ Ifølge politiet blev dommen modtaget med tilfredshed i den sønderjyske befolkning, da man derved undgik at skabe martyrer. ${ }^{61}$ 


\section{Konflikten skærpes yderligere - håndgribeligheder mod Jørgen Warming}

Thomas Pørksens had til Jørgen Warming gav sig også korporlige udslag. Den 9. december 1937 overfusede han Warming på Jørgensens smedje i Stollig med ordene: »Der kommer den idiot, den røver, den petot «. Warming ignorerede dette og gik ind i smedens privatbolig for at betale sin regning. Da han nogle minutter senere kom ud, greb Pørksen fat i brystet på ham, skældte ham ud, truede ham med klø og skubbede ham tilbage mod et gelænder. Først da en anden kunde, Adolf Schmidt, gik ud og sagde til Pørksen: »hold nu hellere op med det Tommy, det har du ikke noget ud af alligevel«, slap han sit greb i Warming. Warming krævede Pørksen straffet for forulempelser og trusler, men denne slap med et polititilhold om at holde sig fra Jørgen Warming. ${ }^{62}$

Der skulle gå næsten to år, før Thomas Pørksen gjorde alvor af sin trussel om at give Jørgen Warming klø. Den 14. august 1939 ved halvnitiden om morgenen var han sammen med sin bror Jes Jürgen på vej til markarbejde ad Knapstien fra Stollig mod Aabenraa. Jørgen Warming kom cyklende i samme retning. Idet han passerede de to brødre, gav Thomas Pørksen ham et skub, så han nær mistede balancen. Derefter greb Pørksen fat i cyklens bagagebærer for at standse Warming, som måtte stå af cyklen. Thomas Pørksen gik løs på Warming med skub og knubs, greb ham om halsen og væltede ham om, så han faldt i grøften. Da han igen rejste sig, gav Jes Jürgen Pørksen ham et kraftigt slag på venstre side af hovedet, så han igen faldt til jorden og et kort øjeblik var bevidstløs. De to brødre gik videre ind mod byen. Da Jørgen Warming igen var kommet på benene, tog han cyklen og kørte den modsatte vej og videre ad en omvej ind til Aabenraa for at melde det passerede til politiet. Han blev undersøgt af en læge, der kunne konstatere, at venstre side af ansigtet var ømfindtligt ved berøring og let hævet. To tjenestekarle fra Strågård, som på en afstand af ca. 400 meter overværede hændelsen, bekræftede Warmings forklaring. Retten i Aabenraa dømte den 25. oktober 1939 Thomas Pørksen til hæfte i 30 dage og Jes Jürgen Pørksen i 20 dage, og sammen skulle de betale Warming $50 \mathrm{kr}$. i erstatning for tort og svie. $^{63}$

Thomas Pørksen havde gode erfaringer med at appellere en dom og gjorde det også i dette tilfælde, broderen og anklagemyndigheden ligeså. Den 8. februar 1940 skærpede Vestre Landsret straffene til 60 


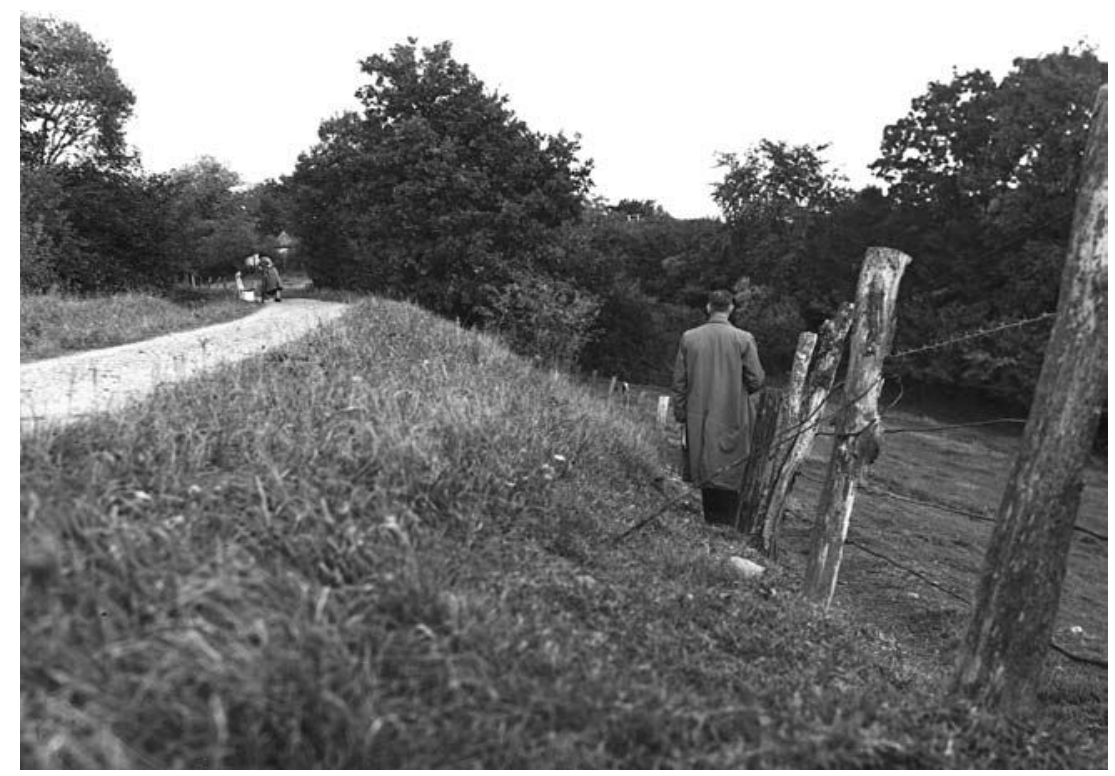

Stedet på Knapstien, hvor Jørgen Warming blev tounget af cyklen, släet og skubbet $i$ grøften af brødrene Thomas og Jes Jürgen Pørksen den 14. august 1939. Foto $i$ RAA, Aabenraa politi nr. 280: Straffeakt 1/1947.

dages hæfte til Thomas Pørksen og 50 dage til Jes Jürgen Pørksen, men gjorde dem til gengæld betinget. ${ }^{64}$

På tærsklen til besættelsestiden blev denne dom den sidste i det juridiske opgør med de kriminelle handlinger rettet imod Jørgen Warming. I mellemtiden var konflikten blevet udvidet til det økonomiske felt. Også her endte modsætningerne i retssalen.

\section{Konflikten udvides - økonomisk boykot af Jørgen Warming}

Som ny ejer søgte Jørgen Warming optagelse som andelshaver i Stollig andelsmejeri. På mejeriets generalforsamling den 23. oktober 1936 fik Jørgen Warming nok lov til fortsat at levere mælk til mejeriet, men hans indmeldelse blev foreløbig stillet i bero. ${ }^{65}$ Det betød, at han ikke kunne få del i mejeriets efterbetaling til sine leverandører. På hesteforsikringsforeningens møde i april 1937 blev Warmings optagelse tilsvarende afvist med 21 stemmer imod og kun 5 for. ${ }^{66} \mathrm{Og}$ på den 
næste generalforsamling i mejeriet den 22. oktober 1937 blev optagelsen af Warming afvist med 28 stemmer imod og 12 for, mens fem stemte blankt. ${ }^{67}$ Økonomisk boykot var således et af de andre midler, som blev taget $\mathrm{i}$ brug for at tvinge Warming fra gården.

På mejeriets generalforsamling den 13. juni 1939 var der på ny en livlig diskussion om optagelse af Warming som andelshaver. Før afstemningen fremlagde gårdejer Peter Frank, formand for Løjt Sogns Danske Samfund, en erklæring, hvis underskrivere nægtede at tage imod den del af efterbetalingen, som rettelig tilfaldt Warming, nægtede at betale til en tabt proces og betragtede Warming som andelshaver. Frank opfordrede andelshaverne til at skrive under på erklæringen i stedet for at deltage i afstemningen. Ud over Frank selv skrev 17 andre under. Afstemningen endte med 23 nej til optagelse, seks ja og fire blanke. ${ }^{68}$

Warming anlagde herefter sag mod mejeriet ved Retten i Aabenraa. L.S. - Landbrugernes Sammenslutning - var generelt imod tvangsauktioner og tilbød at betale mejeriets sagfører. På mejeriets ekstraordinære generalforsamling den 10. juli betonede organisationens lokale repræsentant, Andreas Bonde fra Barsmark, »det sammenhold der burde være indenfor L.S., her gjaldt det om at samles og værne om hjæmmet uden at se på nationale følelse[r].« 27 stemte for proces, 25 imod og en blankt. ${ }^{69}$

Retten i Aabenraa henviste sagen til Vestre Landsret, hvor den blev optaget til doms den 26. februar 1940. Ifølge landsretten var leverance af mælk til det nærmest liggende mejeri en nødvendighed for en gård, sådan som driftsmåden normalt var. Enhver mælkeproducent inden for mejeriets naturlige forretningsområde kunne derfor forlange optagelse, med mindre han havde udvist »en foreningens interesser modstridende handlemåde«. Der forelå imidlertid intet om, at Warming havde modarbejdet mejeriet, hvis formål var rent økonomisk. Efter vedtægterne behøvede han end ikke som ny ejer af en ejendom, hvorfra der hidtil var leveret mælk til mejeriet, at søge om optagelse. Landsretten gav således Warming fuldt medhold. ${ }^{70}$

Sideløbende med de kriminelle handlinger og den økonomiske boykot imod Warming spredte konflikten sig fra Stollig ud i den sønderjyske landsdel som helhed. Dette førte til fornyede opgør i retssalene. Det hårdeste udsprang af de nazistiske mindretalslederes angreb på de danske justitsmyndigheders håndtering af Stolligaffæren. 


\section{Konflikten spredes - Flyvebladsaffæren og sagen mod Weber og Larsen}

Den 28. august 1937 blev 35.000 stk. af et flyveskrift med titlen Sandheden om Stollig-Affæren overgivet til postvæsnet. Det samlede oplag var på 50.000 og trykt i Nordschleswigsche Zeitungs trykkeri. Ansvarshavende var dyrlæge Jens Møller, Gråsten. Med sine tre artikler "Sandheden om Stollig-affæren«, »Justitia på gale veje« og »En syndebuk skal findes « blæste flyveskriftet til frontalangreb på de involverede justitsmyndigheder. ${ }^{71}$

Ifølge politiet indeholdt flyveskriftet ærekrænkende udsagn om kriminalpolitiet og politimester Agersted i Aabenraa, statsadvokat Holm i Sønderborg samt dommerne i Aabenraa og ved Vestre Landsret. Statsadvokat Holm havde ifølge flyveskriftet »vildledt offentligheden « og gentaget »usandfærdige fremstillinger «. Flyveskriftet talte endvidere om »Den historie, som også statsadvokaten serverede for landsretten«. Om fængslingen af Jep Schmidt hed det, at »ingen ved med hvilken saglig begrundelse « den skete, hvilket blev gentaget: »Uden spor af grundlag har man således i 11 dage holdt Jep Schmidt fængslet«. Om politiets anklage mod Nis Lorenz Closter bemærkede flyvebladet: "En velanbragt henvisning til Luthers katekismus er i Danmark altså en kriminel handling «. Om anklagen mod Pørksen stod: »Vi ved, lige så godt som politiet, at Thomas Pørksen er fuldstændig og absolut uskyldig «. Videre hed det: »Det danske kriminalpoliti har til trods for mange måneders ihærdige undersøgelser ikke opbragt et eneste bevis, der hentyder til, at Th. Pørksen kan være gerningsmanden «, ligesom »Hele anklagen mod ham og Jep Schmidt er som sagt i forsvarstalen grebet ud af luften i den mening, at noget bliver der vel hængende«. Anklagen blev betegnet som »fri fantasi« og »støttet på løse formodninger«. Endelig hed det: »Det kommer sig ikke så nøje, hvem der bliver straffet. Hovedsagen er, at der statueres et eksempel 'til afsky og til skræk'«. For disse ytringer blev Jens Møller sat under tiltale ved retten i Aabenraa. Da flere udsagn var gentaget i Nordschleswigsche Zeitung, stod avisens ansvarshavende redaktør Kardel også som tiltalt.

Tiltalen mod Møller inddrog desuden en artikel i Nordschleswigsche Zeitung den 30. juli 1937, hvor han kaldte dommen over Pørksen ved retten i Aabenraa og i Vestre Landsret for en »oprørende fejldom«. Artiklen påstod endvidere, at »denne metode fra den danske justits $\mathrm{i}$ 
grænselandet vil give sværere nakkedrag, end herrerne i Viborg aner « og stillede spørgsmålet: »eller tror den høje ret i Viborg, at sådanne løse holdepunkter er nok, fordi det drejer sig om en tysker«.

Ud over Møller og Kardel stod også Lorenzo Christensen tiltalt for ærekrænkende ytringer i to artikler i Nordschleswigsche Zeitung den 28. og 29. juli 1937. Her beskyldte han statsadvokaten for at have fremsat »en række af urigtige for ikke at sige usande påstande«, ligesom han skrev: »en løgn bliver ikke til sandhed ved, at den hele tiden gentages «. Holm var tillige optrådt med »en enestående usandhed «. Om Holm hed det yderligere: "Statsadvokat Holm har jo allerede flere gange repræsenteret anklagemyndigheden over for bønder, som man ville have fat i kraven på«. Videre mente Christensen, »at statsadvokat Holm på ingen måde forstår nødvendigheden af en samvittighedsfuld retsprøvelse«.

I anklageskriftet krævede anklagemyndigheden i første omgang, at de anklagede fik frataget deres borgerlige rettigheder. Dermed ville de miste deres ret til at beklæde offentlige hverv, stemmeret, valgbarhed, ret til at udøve autoriserede erhverv, herunder som dyrlæge, samt ret til pension, understøttelse m.m. ${ }^{72}$ Kravet var en taktisk brøler, som medførte stærke indsigelser i tysk presse. ${ }^{73}$ Den tyske gesandt i Danmark, Cecil von Renthe-Fink, fortalte efter ordre fra Auswärtiges Amt omkring den 1. november 1937 udenrigsminister Peter Munch, at en dom over de tre tiltalte ville føre til en uønsket skærpelse af modsætningerne i grænselandet, navnlig hvis den førte til en frakendelse af deres borgerlige rettigheder. Munch svarede, at man fra regeringens side ikke kunne øve megen indflydelse på rettens gang. Gesandten talte også den 24. november med statsminister Stauning og fortalte, at den tyske folkegruppes situation i Nordslesvig måtte påvirke det dansk-tyske forhold. Stauning svarede, at det man fra dansk side vendte sig imod, var den overdrevne form, som den nationalsocialistiske propaganda benyttede sig af. Som officiel repræsentant for Tyskland lagde Renthe-Fink således et pres på de danske myndigheder. ${ }^{74}$ Den 1 . december frafaldt anklagemyndigheden sit krav. ${ }^{75}$ Hvorvidt dette var et resultat af presset fra gesandten og den tyske offentlighed, må imidlertid stå hen i det uvisse.

Retten i Aabenraa fandt den 5. december 1937 alle tre tiltalte skyldige. Ved strafudmålingen ansås det for et formildende moment, at de alle tre var overbeviste om Pørksens uskyld, mens det var en skærpende omstændighed, navnlig i Møllers og Christensens tilfælde, at 


\section{Sandheden om Stolligid-Afiferen}

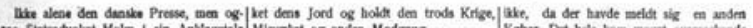

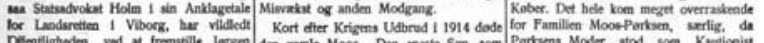
Defentightoden vod at fremsellle Jorgen Jen gamle Mook. Den eneate Son, soen Portivens Moder stod som Kastionist

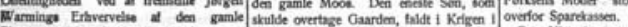

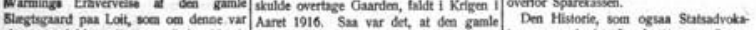

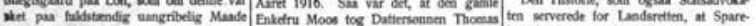

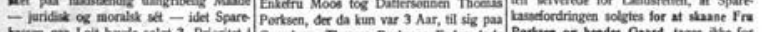

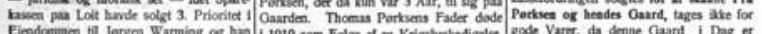
Ejendomimen til Jorgen Warming og han 11919 som Felge af en Krigsbelkadigele,

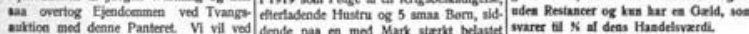

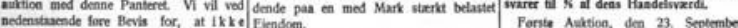

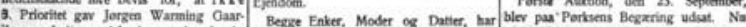

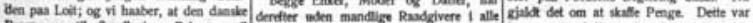
Presse - esil Sandhedens Pris - vil de Aar drevet begze Clando med frem- fo mere ranskeligt, it der nu ogau

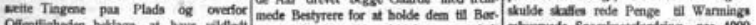

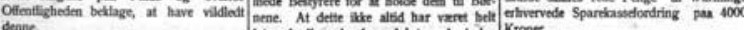
Iht ved alle, der tar fulgt med i deen Kroner.

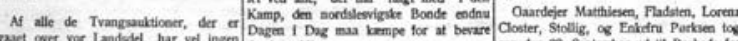
gavet over vor Landedel, har vel ingea Jard og Hikm.

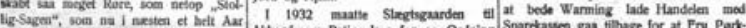
har veret Oenstand for Aviapolenilk og Aktord, og Betingedsen for en Ordning Sparchasten gas tillbage for at Fru Part-

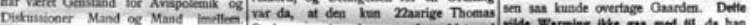

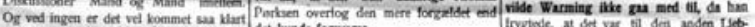
uf Udtryk, at vore hjemllge gamle Plonde Get kunde fonvars.

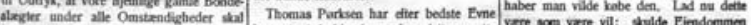

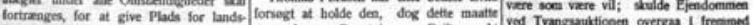

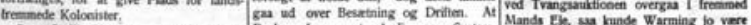

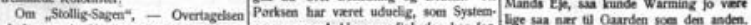

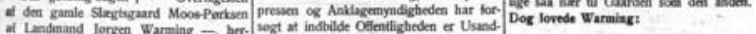

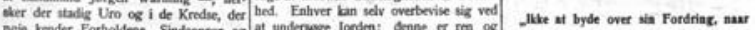

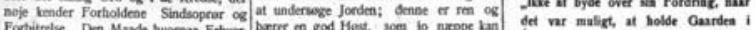
Fortitrelise. Dea Mande hworpaa Ertiver
velseg fander en god Host, soen fo nappe han

velsen fanit Sied, glemmes like sa let vare Jargen Warnings Fortjeneste, da Slagtens Ejer.

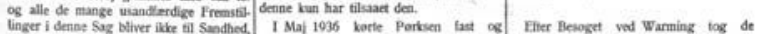

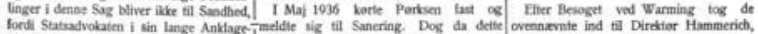

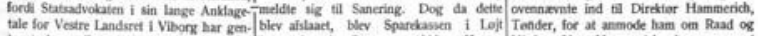

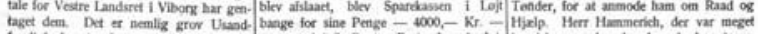

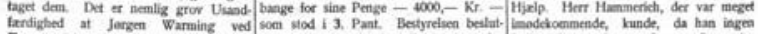

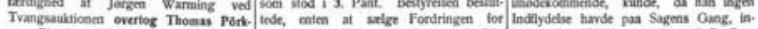

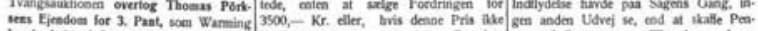

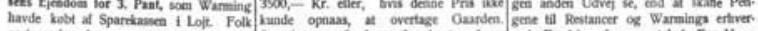

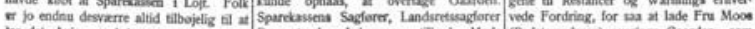

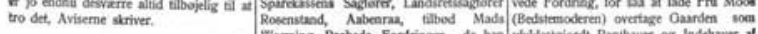

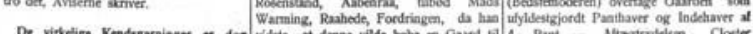

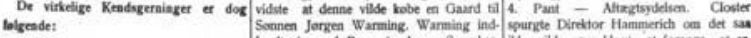

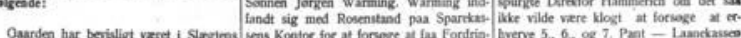

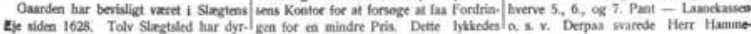

Dette flyveblad var med sin skarpe kritik af politi, statsadvokat og domstole mere end de danske justitsmyndigheder ville acceptere. Det blev forbudt og den ansvarshavende redaktør, dyrlæge Jens Møller, sat under anklage. Da Møller var fører for mindretallets nazistparti NSDAP-N, blev anklagen anledning til en hård konflikt mellem mindretal og herbergstat. RAA, Politiadjudanten for de sønderjydske Landsdele nr. 186: Journalsag 5156.

der var fremsat »grove sigtelser for justitsvilkaarlighed og partiskhed « og i Møllers tilfælde desuden, at beskyldningerne efter planen skulle udbredes for en meget stor kreds af befolkningen. Jens Møller blev derfor idømt 60 dages hæfte, mens Harboe Kardel slap med en bøde på $150 \mathrm{kr}$. og Lorenzo Christensen en bøde på 500 kr. Alle eksemplarer af flyveskriftet skulle inddrages. De tre tiltaltes påstande blev endelig kendt ubeføjede. Dommer var Asger Rasmussen fra retten i Frøs og Kalvslund Herreder, idet den lokale dommer Levinsen jo var inhabil. 
Dommen førte til en stribe af protestmøder i mindretallet. Den 7. december 1937 var der møde i Aabenraa med NSDAP-N's kredsledere og lokalgruppeledere sammen med SK-førerne; SK stod for Schleswigsche Kameradschaft svarende til det rigstyske SA. Lederne stillede sig ubetinget bag partifører Jens Møller, der var ramt af »en dansk domstols fulde hårdhed ", og erklærede, at de »trods alt marcherer ind i en ny fremtid! ${ }^{76}$ Der blev afholdt protestmøder den 9. december $i$ Tønder, den 10. i Rinkenæs, Haderslev og Sønderborg, den 11. i Højer, den 14. i Øster Terp og den 15. i Nørre Løgum. I resolutionen fra Tønder hed det: »Tyske folkefæller forsamlet på Skyttegården i Tønder, nedlægger protest imod dommen over deres kammerater. De lover dobbelt indsats i kampen mod fremmedgørelse og for hjemmehørighed. De bekender sig til solidaritet med det af Adolf Hitler forenede folk og vil uanfægtet marchere videre. Nordslesvig, vågn op!«. I Nørre Løgum var resolutionen mere afdæmpet og uden nazistiske fraser: »Nørre Løgums tyskhed stiller sig bag de dømte kammerater og lover forstærket indsats i kampen for den tyske folkegruppes fremtid.«77

Dommen gjorde også et stærkt indtryk i den tyske presse og i det tyske udenrigsministerium. Den tyske gesandt i København skrev til Auswärtiges Amt, at dommen var både ubegribelig og uklog og havde forværret klimaet i grænselandet. Han fandt dog også, at man burde give »hedsporerne i Nordslesvig « besked på, at de ikke skulle regne med rygdækning fra Tyskland, hvis de overskred visse grænser. Den samme indstilling havde gesandtens overordnede i Auswärtiges Amt, som satte sig for at gyde olie på vandene. Den tyske presse blev informeret om ministeriets holdning, og det samme gjorde overpræsident og gauleiter Lohse i Kiel. Jens Møller blev opfordret til at appellere dommen, hvilket han oprindelig var utilbøjelig til - måske søgte han martyriet? ${ }^{78}$

Dommen blev anket til Vestre Landsret. I sin dom af 9. februar 1938 omgjorde landsretten Jens Møllers hæftestraf til en bøde på $2.000 \mathrm{kr}$. og stadfæstede dommene over Kardel og Christensen. To dommere mente, at Kardel burde frifindes og bøderne for Møller og Christensen sættes ned til 1.000 og $250 \mathrm{kr}^{79}$ De tre dømte ansøgte uden held Justitsministeriet om at få nedsat bøderne. ${ }^{80}$

Landsrettens nedsættelse af Jens Møllers straf faldt i samme måned som Højesterets frifindelse af Schmidt og Pørksen. De to ting i forening bevirkede sammen med det tyske Udenrigsministeriums ind- 
sats en vis afspænding. ${ }^{81}$ De to domme gav endvidere anledning til kritik af de sønderjyske justitsmyndigheder. Nationaltidende angreb politiadjudant Kresten Refslund Thomsen hårdt. ${ }^{82}$ Vilhelm la Cours kritik i Grænsevagten var mere moderat. Om Stolligsagen skrev han: »Med det udfald, sagen fik, skal vi intet skjul lægge på, at vi hellere havde set frifindelsen falde allerede i Aabenraa. En dom i en sag, der af det hjemmetyske mindretal med vold og magt er stemplet som nationalpolitisk, må ikke kunne udsættes for at blive afsvækket, hvis den af det offentlige indankes for højere instanser. Der må tværtimod foreligge en ubetinget, en aldeles overvejende sandsynlighed for, at den vil blive skærpet, i det allermindste stadfrestet. « La Cour fandt det såre menneskeligt, at de lokale justitsmyndigheder fulgte en hårdere kurs end de overordnede, præget som de var af den standende nationale kamp: »Man har selvsagt sin jura i den bedste orden. Man dømmer på ingen måde "galt«, og man udformer ikke et anklageskrift i strid med de gældende retsprincipper. Men man går indtil grænsen af det, der kan kræves!«. La Cour fandt det skadeligt, at de lokale justitsmyndigheder nu var blevet underkendt: »Gentages noget sådant, vil forholdet virke ødelæggende for de lokale grænseinstitutioners autoritet $« .83$

De nazistiske ledere i mindretallet bidrog ikke til en afspænding. Efter Højesterets frifindelse af Schmidt og Pørksen den 18. februar 1938 blev der udgivet et nyt flyveblad Oliepletten fra Stollig, trykt hos Nordschleswigsche Zeitung med Peter Larsen som ansvarshavende. Undertitler var denne gang »Tilbage blev dumhederne" og "Statsadvokat Holm og politiadjudanten endnu i embede! «. ${ }^{84}$ Man følte sig tydeligvis ovenpå: »Stollig-affæren og flyvebladsprocessen - derom hersker der vist ikke delte meninger - er blevet et dundrende nederlag for danskheden i grænseområdet. « Der blev ikke rejst sag mod udgiveren, og Peter Larsen kom ikke for retten i denne omgang.

Kritikken af de sønderjyske justitsmyndigheder fortsatte. Gartnermedhjælper Chresten Weber fra Rødekro og Peter Larsen gentog i læserbreve i Nordschleswigsche Zeitung den 26. og 27. april 1939 adskillige af flyvebladenes kritikpunkter med stort set de samme vendinger. Retten kendte kritikken ubeføjet og idømte Weber 30 dagbøder á fem kr. og Larsen 50 dagbøger á otte kr. for ærekrænkelse. ${ }^{85}$

I sin helhed blev de nazistiske mindretalslederes udvidelse af Stolligaffæren ved at optrappe den til et generalangreb på landsdelens danske justitsmyndigheder således mødt hårdt imod hårdt. Deres sagsanlæg mod dagbladet Hejmdal virkede heller ikke. 


\section{Konflikten spredes - fornærmelsessagen imod Hejmdal}

Den 2. september 1937 skrev Hejmdal i en usigneret artikel »Tonen stemmes ned «: »Vi forstår så godt, at folk som P. Larsen, dyrlæge Møller og dr. Lorenzo Christensen føler sig ilde til mode nu, hvor de ser resultaterne af deres ophidselse, hvorved de har ført en ung mand i ulykke. Det ansvar er tungt nok at bære for folk, der vil anses og kaldes for politiske førere og vejledere. Og det tyske blad har sit medansvar, fordi det har givet disse mænd lov til at tumle sig i bladets spalter.«

Denne passage fandt de tre nævnte personer »i høj grad ærekrænkende «, og de anlagde en injuriesag ved Retten i Aabenraa mod Hejmdals ansvarshavende redaktør Bjørn Hanssen. ${ }^{86}$ Bjørn Hanssen vedstod i retten, at han selv havde skrevet artiklen og hentydet til Pørksen. Han bestred, at han havde tillagt sagsøgerne et direkte ansvar for forbrydelserne mod Warming, men nok hævdet »at sagsøgerne ved deres artikler, taler og hele optræden har skabt et spændt forhold mellem de to nationaliteter i grænselandet og derved har et moralsk ansvar for, at forholdet mellem disse ikke er fordrageligt. « Peter Larsen fremkom med nogle drastiske udtalelser i retten. Ifølge Hejmdal sagde han til dommeren: »Hvis dommen kom til at lyde på frifindelse, eller en lille bøde, ville han gerne spørge, om det var tilladt at traktere »denne person « med hundepisken! «. Hertil svarede Levinsen stilfærdigt, at det måtte han ikke. ${ }^{87}$ Retten frifandt den 25 . november 1937 Bjørn Hanssen.

Frifindelsen var en begmand til de tre nazistiske mindretalsledere. Retten havde statueret, at det var lovligt at tilkende dem et moralsk ansvar for forbrydelserne mod Warming. Havde de haft en mere nøgtern vurdering af sandsynligheden for at få Bjørn Hanssen dømt, havde de næppe rejst sagen. Måske dækkede deres stærke vrede mod Bjørn Hanssen over en dårlig samvittighed.

\section{Konflikten afvikles}

Efter den tyske invasion af Danmark den 9. april 1940 forsøgte Jep Schmidt med et brev til justitsministeren at videreføre konflikten i håb om gunstige resultater i læ af de tyske bajonetter: »Henstiller herved på mine folkefællers vegne om omgående fjernelse af den jø- 
diske dommer, Niels Levinsen fra dommersædet i Aabenraa. Levinsen har, grundet på sin fanatiske had til den tyske nationalsocialisme mistet alle forudsætninger, som stilles til en dommer. Såvel partifører dr. Møller, organisationsleder overleutn. Larsen som undertegnede har været udsat for denne jødes hadinstinkter.« Endvidere henstillede han, at der indledtes skridt til at få Jørgen Warming fjernet fra gården i Stollig. Truende hed det: "Den dybe harme i befolkningen vil ellers i nær fremtid kunne give anledning til alvorlige konsekvenser.« Brevet var dateret den 19. juni 1940, og Jep Schmidt levede som mange andre i det tyske mindretal endnu i håbet om en grænseflytning. ${ }^{88}$

Dommer Levinsen blev ikke fjernet. ${ }^{89}$ Forsøget på at fjerne Warming fra gården mislykkedes også. En optrapning af Stolligkonflikten passede ikke ind i samarbejdet mellem den danske regering og besættelsesmagten om en fredelig afvikling af den tyske okkupation. Grænseflytningen blev af samme grund heller ikke til noget. I stedet faldt Stolligaffæren til ro. Den fusede ud, fordi den blev overlejret af en ny og stærkere dagsorden.

\section{Konklusion}

Stolligaffæren havde sin rod i Første Verdenskrig, som kostede den udsete arving til en gård i Stollig livet. I stedet måtte dattersønnen Thomas Pørksen træde til som gårdejer i en meget ung alder og uden de nødvendige forudsætninger for at drive gård. Under krisen i 1930'erne måtte han opgive gården, som kom på tvangsauktion. Fordi de tyske mindretalsledere på Løjt Land og Kreditanstalt Vogelgesang ikke kendte deres besøgelsestid, endte auktionen med, at gården gik fra tysksindede over på dansksindede hænder. På dansk side så centrale personer og institutioner i jordkampen muligheden. Jørgen Warming blev ny ejer efter formidling via direktør Martin Hammerich og med støtte fra A.P. Møller og Landeværnet, udvirket af Hans Jefsen Christensen.

Tvangsauktioner var der i hundredvis af i 1930'ernes Sønderjylland, og ejerskifter på tværs af sindelagsgrænserne forekom også. Når tilfældet fra Stollig vakte så stor opmærksomhed, skyldtes det, at Jep Schmidt, Peter Larsen og Jens Møller kunne udnytte det til en tredobbelt politisk profilering. Ved at fremstå som de kriseramte sønderjyske landmænds handlekraftige talsmænd i protesten mod det danske »system « kunne de vinde øget tilslutning til mindretallet. Til dette formål blev der trukket kraftigt på nazistiske Blut und Boden forestillinger, 
der i Tyskland og særlig i Sydslesvig havde vist sig effektive for NSDAP i kampen om bøndernes stemmer. Ved at agere idealistiske forkæmpere for nazismen i sin helhed kunne de hjemmetyske nazistiske frontfigurer forstærke deres position i mindretallet overfor de traditionelle nationalkonservative ledere. Og ved at være aktive og pågående kunne de fremme NSDAP-N's stilling i konkurrencen med NSAN. Deres handlinger var ikke kun drevet af taktiske overvejelser. De havde fundet frelsen i nazismen og var forblændet af Tysklands genvundne stormagtstatus. De førte sig frem over for den danske modstander, herunder myndighederne, med et overmod, som kun kan skyldes, at de troede på et umiddelbart forestående gennembrud for nazismen også i Nordslesvig.

De metoder, som blev taget $\mathrm{i}$ anvendelse for at chikanere Jørgen Warming væk fra gården, var tydeligvis inspireret af SA's fremfærd i Tyskland. De var fremmede for den demokratiske politiske kultur, som dominerede i Danmark. Det var den anonyme diffamering af Jørgen Warming som tyv, røver og kæltring i graffiti og breve uden afsenderadresse og den knap så vidtgående offentlige udhængning i avisindlæg og flyveblade. Det var intimidering af Warming gennem offentlige og anonyme trusler om at huske ham, når regnskabet skulle gøres op, og ved happenings som »genindsættelsen« af Thomas Pørksen og »trampemarchen« forbi hans gård. Det var gennem økonomisk boykot sigtende mod at nægte Warming fordelene ved at stå som andelshaver i mejeri og hesteforsikring og mod at isolere ham i lokalsamfundet. Det var ved hærværk rettet mod Warmings bygninger og maskiner, alvorligst ved forgiftningen af hans brønd. Det var endelig ved direkte vold $\mathrm{i}$ form af skub og slag ledsaget af overfusning.

De skyldige i de kriminelle overgreb lod sig kun delvist finde. Nis Lorenz Closter blev dømt for at sende Luthers lille katekismus til Jørgen Warming med det niende bud rødt indstreget. Brødrene Thomas og Jes Jürgen Pørksen blev tilsvarende dømt for et korporligt overfald på Warming. Det lykkedes derimod ikke at skaffe sikre beviser for, hvem der stod bag det omfattende hærværk. Sikkert er det imidlertid, at Jep Schmidt var den åndelige anstifter af samtlige overgreb. Med sine ubeherskede angreb i læserbreve og "genindsættelsen « af Pørksen på gården skabte han det politiske klima, hvori yderligtgående aktioner kunne finde sted. Med sin meget vidtgående forståelse for de metoder, der blev taget i brug imod Warming, påtog Peter Larsen sig ligeledes et moralsk medansvar. 


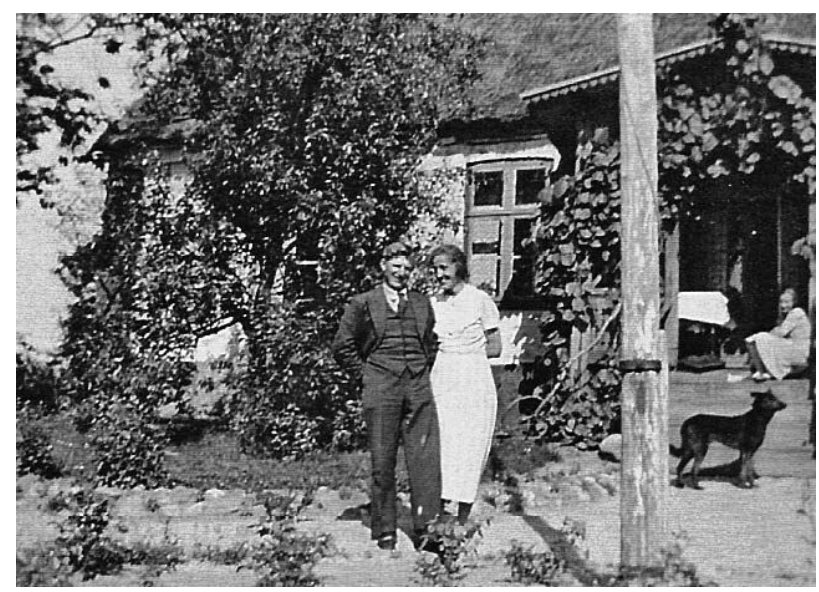

Jørgen og Grethe Warming i haven 1937. Parret lod sig ikke chikanere bort fra gården, som stadig er $i$ familiens eje. Foto i privateje.

Dette moralske medansvar gjaldt i første række over for Jørgen Warming, men også i forhold til Thomas Pørksen. Han blev Stolligaffærens tragiske skikkelse. Oprindelig syntes han indstillet på at forlade sin gård, men han blev ved Jep Schmidts avisindlæg og happening skubbet ind i en martyrrolle, som han tydeligvis ikke magtede. Dertil savnede han det rolige overlæg og den selvbeherskelse, som var nødvendig, og som Jørgen Warming besad.

De danske justitsmyndigheder - politiet og dommeren i Aabenraa, statsadvokaten i Sønderborg, Vestre Landsret og Højesteret - blev under Stolligaffæren stillet i en vanskelig situation. Især de lokale myndigheder nærede et stærkt ønske om at finde frem til de skyldige i overgrebene mod Warming. Det var velbegrundet i hensynet til at holde kriminelle metoder ude af den nationalpolitiske kamp, og som tiden var efter 1933, ville det i første række sige metoder importeret fra Nazityskland. Derfor iværksatte politiet i Aabenraa en ihærdig efterforskning, ligesom statsadvokaten forlangte strenge straffe, som dommeren i Aabenraa i vid udstrækning idømte. Dette gjaldt både i selve »Stolligsagen« og i »Flyvebladsaffæren«. De lokale justitsmyndigheder var villige til at gå meget langt for at sikre eftertrykkelige domfældelser - så langt, at proportionssansen undertiden led skade. Men heller ikke de overordnede instanser syntes fremmede over for politiske overvejelser. De førte blot til det modsatte resultat. Det er således påfaldende, at ingen overhovedet af de anklagede blev idømt 
ubetinget hæfte eller fængsel i sidste instans, end ikke brødrene Pørksen for deres håndgribeligheder mod Warming. Om det var for at undgå at give dem martyrstatus eller af ulyst til at udfordre den store nabo mod syd, kan ikke afgøres. Den forskellige indstilling hos instanserne førte til tab af autoritet, især lokalt, og Jep Schmidt og Jens Møller blev iscenesat som martyrer for tyskheden og fik dermed gode kort på hånden i den interne magtkamp i mindretallet. At Jens Møller og Peter Larsen overspillede deres kort ved uigennemtænkte anklager i flyveblade og ubeherskede taler i retten, ændrede ikke grundlæggende ved dette.

Afslutningsvis skal det ikke glemmes, at der på tysk side var kræfter, som var kritiske over for de nazistiske mindretalslederes håndtering af Stolligaffæren. Det var dels gamle nationalkonservative som pastor Schmidt og sagfører Vogelgesang, dels det tyske Auswärtiges Amt, som søgte at dæmpe gemytterne.

\section{Udblik}

Efter Stolligaffæren gennemgik dens hovedaktører vidt forskellige livsforløb. Blandt de tre tiltalte i Stolligsagen gled Thomas Pørksen tilbage i anonymiteten. Nis Lorenz Closter blev under Besættelsen ansat hos Sicherheitsdienst og Gestapo og deltog i mishandlingen af danske modstandsfolk. Ved retsopgøret blev han dømt til døden i tre instanser, men blev benådet og i stedet sat i fængsel på livstid. I 1957 blev han løsladt på grund af alvorlig sygdom og døde ganske kort efter. ${ }^{90}$ Jep Schmidt indgik som kredsleder i NSDAP-N i »det lille politiske råd «, hvor de centrale beslutninger om mindretallet under Besættelsen blev truffet. Han meldte sig som frivillig til Waffen-SS og deltog i krigen på østfronten. Ved retsopgøret blev han idømt otte års fængsel. Efter en årrække genoptog han i 1966 sin politiske karriere i Løjt sogneråd for Slesvigsk Parti. Efter kommunalreformen i 1970 blev han medlem af Aabenraa byråd og opnåede i årene 1974-78 posten som viceborgmester, fordi Slesvigsk Parti var tungen på vægtskålen. Jens Møller og Peter Larsen blev idømt endnu strengere straffe og forblev politisk set ude af billedet. ${ }^{91}$ Jørgen Warming blev på sin gård. ${ }^{92}$ Hans familie bebor stadig ejendommen, hvis smukt restaurerede stuehus i 2013 opnåede en pris for vellykket istandsættelse. ${ }^{93}$ Stolligaffærens stridsgenstand eksisterer dermed i bedste velgående, længe efter at dens aktører er lagt i graven. 


\section{KILDER}

\section{Utrykte kilder:}

\section{Rigsarkivet København (RAK):}

Udenrigsministeriet nr. 7-266, gruppeordnede sager 7.X.17h: Tvangsauktion over Ejendom i Stollig (Warming - Pørksen).

Rigsarkivet Aabenraa (RAA):

Aabenraa amtsret nr. 882: Grundbog for Stollig bind I.

Aabenraa politi nr. 280: Straffeakt 1/ 1947 vedr. Thomas Pørksen

Politiadjudanten for de sønderjydske Landsdele nr. 186: Journalsag 5156; nr. 191: Journalsag 5579; nr. 276: Beretning for 1938.

Retten i Aabenraa nr. 354: Borgerlig sag 320/37, dyrlæge Møller, Graasten, m.fl. mod redaktør Bjørn Hanssen, Aabenraa; nr. 363: Borgerlig sag 274/ 39 , gårdejer Jørgen Warming, Stollig, mod Stollig andelsmejeri; nr. 862: Dombog for Straffesager IX; nr. 863: Dombog for Straffesager X; nr. 1614: Tvangsauktionssager 1936 nr. A 27.

Retten i Aabenraa, tinglysningen, $\mathrm{nr}$. 689: Aflyste skøder og servitutter, Stollig nr. 14.

\section{LITTERATUR}

Becker-Christensen, Henrik: Det tyske mindretal i Nordslesvig 1920-1932, I-II. Aabenraa 1990.

Becker-Christensen, Henrik: »Fra »mod hinanden « til »med hinanden " 19182008«, Sønderjyllands Historie bind 2. Aabenraa 2009, s. 241-472.

Callø, P.A. og Iversen, Peter Kr. (udg.): Aktstykker vedrorende Kreditanstalt Vogelgesangs Tilblivelse. Aabenraa 1946.

»Dagshistorie 1904«, Sønderjyske Årbøger 1905, s. 307-318.

Fransen, Peter: "Statspolitiet", Peter Fransen m.fl.: Harmonisering eller særordning. Sønderjylland som administrativ forsøgsmark efter Genforeningen $i$ 1920 - bind 1. Aabenraa 2002, s. 87258.
Kreditanstalt Vogelgesangs arkiv nr. 1338: Akte I 2906; nr. 1340: Akte I 3063.

Landeværnets arkiv acc. 449/81: Lånesag A 2896.

Løjt Sogns Sparekasse nr. 491/16: Lånesager 1920-46.

Stollig andelsmejeris arkiv nr. 447/4: Forhandlingsprotokol.

Det tyske mindretals arkiver nr. 1134, Nordschleswigsche Zeitung: Sager og avisudklip vedr. Stolligaffæren og flyvebladsprocessen 1936-38.

Hans Jefsen Christensens privatarkiv nr. 98/38: Sager vedr. skibsreder A.P. Møller (jordkampen) 1935-56.

Trykte kilder:

Flensburger Nachrichten.

Grænsevagten (forkortet Grv.).

Göteborgs Handels- och Sjöfartstidning.

Hejmdal.

Jydske Tidende.

JydskeVestkysten.

Lovtidende 1930.

Nordschleswigsche Zeitung (forkortet NZ).

Nordslesvig venter.

Rigsdagstidende. Forhandlinger i Folketinget 1936/37, bind III.

Holdt, Jes M.: Gårde og Slægter i Løjt sogn. Aabenraa 1982.

Hopp, Peter: »Bodenkampf und Bauernbewegung. Von der Anfangsphase der Kreditanstalt Vogelgesang bis zum Ende der Sammlungsbewegung", Zeitschrift der Gesellschaft für Schleswig-Holsteinische Geschichte Bd. 100, 1975, s. 222-241.

Kraks Blå Bog, København 1955.

Larsen, Henning N.: Benådet. 32 dødsdømte danskere, der slap for henrettelse. København 2014.

Lenzing, Hilke: Die deutsche Volksgruppe in Dänemark und das nationalsozialistische Deutschland (1933-1939), Diss. Bonn 1973. 
Luther, Martin: »Dr. Martin Luthers lille Katekismus for ulærde sognepræster og prædikanter", Grane, Leif: Den danske Folkekirkes Bekendelsesskrifter. København 1981, s. 102-123.

Schultz Hansen, Hans: »Tidsrummet 1864-1970«, Hans H. Worsøe (red.): Løjt sogns historie. Aabenraa 1988, s. 223-351.

Schultz Hansen, Hans: Det sønderiyske landbrugs historie 1830-1993. Aabenraa 1994.

\section{NOTER}

1. Göteborgs Handels- och Sjöfartstidning 8.1.1938.

2. Læserbrev i NZ 18.12.1937. Oversættelse efter Grv. 1938, s. 34f. Se også her oversættelse af læserbrev ved W. Knudsen i NZ 16.12.1938.

3. Betegnelsen dukker op i Hejmdal 22.10.1936: »Tyske Nazister søger at lave en »Affære« i Stollig«. Samme 27.10.1936, udtalelse af Peter Frank, Stollig, under overskriften »Stolligaffæren «.

4. RAK, Udenrigsministeriets arkiv nr. 7-266.

5. Fransen 2002, s. 215-227.

6. Tägil 1970, s. 93-97. Lenzing 1973, s. 127-130.

7. Schultz Hansen 1988, s. 318f.

8. Se om jordkampen Becker-Christensen 1990, s. 138-179; Hopp 1975; Callø og Iversen 1946; Schultz Hansen 2002.

9. Se om krisen i 1930'erne i Schultz Hansen 1994, s. 241, 279-301.

10. Becker-Christensen 2009, s. 322-327. Endvidere Tägil 1970.

11. Om forholdene i Løjt, se navnlig Schultz Hansen 1988, s. 222-352, 366372.

12. Holdt 1982, s. 165-169. RAA, Aabenraa amtsret nr. 882, grundbog for Stollig bind I blad 4.

13. Holdt 1982, s. 159-161.

14. RAÅ, Retten i Aabenraa nr. 1614, købekontrakt af 2.6.1933 og tingbogsudskrift af 16.4.1936.
Schultz Hansen, Hans: "Dansk jord på danske hænder". Foreningen Landeværnet og den nationale jordkamp i Sønderjylland 1927-2002. Aabenraa 2002.

Schultz Hansen, Hans: »Så har vi dem igen « - kontinuitet og brud i det tyske mindretals ledelse hen over 1945", Sønderjyske Årbøger 2014, s. 313-334.

Tägil, Sven: Deutschland und die deutsche Minderheit in Nordschleswig. Eine Studie zur deutschen Grenzpolitik 19331939. Lund 1970.

15. RAÅ, Kreditanstalt Vogelgesang nr. 1338, Christensen til Vogelgesang 17.4.1936 og svar 20.4.1936.

16. Når det siden fra tysk side under retssagerne hævdedes, at Pørksen var en dygtig landmand, var det mod bedre vidende. Se RAA, Kreditanstalt Vogelgesang, nr. 1340, notits 20.10.1937, brev til Jep Schmidt 25.10.1937, brev fra landsretssagfører Clausen til Schmidt 8.11.1937, brev fra Jep Schmidt 12.11.1937 og til Jep Schmidt s.d. Det fremgår heraf, at en oprindelig redegørelse fra Vogelgesang til brug for Jep Schmidt i Højesteret blev redigeret således, at dens omtale af Pørksens manglende landmandsevner udgik. Se også Flensburger Nachrichten 8.2.1938.

17. RAÄ, Retten i Aabenraa nr. 1614 . Endvidere RAK, Udenrigsministeriet nr. 7-266, beretning ved landsretssagfører Rosenstand 27.10.1936 til Aabenraa-Sønderborg Amt. RA Løjt Sogns Sparekasse nr. 491/16, breve fra lrs. Rosenstand til sparekassen 18.12.1935 og 27.5., 3.6., 22.7., 6.8. og 2.9.1936.

18. RAK, Udenrigsministeriet nr. 7-266, notat ved Knud Glente, AabenraaSønderborg amt, dateret 27.10.1936, om samtale med lrs. Rosenstand. Mads Warmings redegørelse i Hejmdal 13.3.1937 under overskriften »Salget af Ths. Pørksens Ejendom«. Martin Hammerichs udaterede be- 
retning [andet halvår 1937] om »Stollig-Sagen « i Udenrigsministeriet nr. 7-266. De tre beretninger er i det væsentligste overensstemmende. Se også Aabenraa politi nr. 280, afhøringer af Mads og Jørgen Warming, Hans Nissen Krap og Jens Iversen 28.5., 10.6. og 11.6.1937, og udskrift fra Løjt Sparekasses protokol 17.9.1936.

19. RAÅ, Kreditanstalt Vogelgesang nr. 1338, notat 11.9.1936.

20. RAA, Kreditanstalt Vogelgesang nr. 1340, brev fra Schmidt 11.9.1936.

21. Se herom RA $\AA$, Retten i Aabenraa nr. 1614, udskrift af auktionsprotokollen 23.9.1936.

22. Warmings redegørelse i Hejmdal 13.3.1937.

23. RAÅ, Aabenraa politi nr. 280, rapport 28.5.1937.

24. Dagshistorie 1904, s. $317 f$.

25. RAK, Udenrigsministeriet nr. 7-266, udat. redegørelse fra Martin Hammerich.

26. RA $\AA$, Kreditanstalt Vogelgesang nr. 1340, brev fra Jebsen 9.10.1936 med bilag.

27. Sst. notat 9.10.1936.

28. Se herom RAA, Retten i Aabenraa nr. 1614, udskrift af auktionsprotokollen 10.10.1936. Rosenstands og Hammerichs beretninger jfr. note 17 og 18. Warmings redegørelse i Hejmdal 13.3.1937.

29. Vogelgesangs arkiv nr. 1340, påtegning på notat af 9.10.1936.

30. RAA, Politiadjudantens arkiv nr. 276, beretning for 1938, s. 9 .

31. RAA, Hans Jefsen Christensen arkiv nr. 98/38, koncept til brev 16.11.1936 samt afskrift af positivt tilsagn fra A.P. Møller til P.A. Callø 21.11.1936. Jfr. Aabenraa amtsrets arkiv nr. 882: Grundbog for Stollig bind I blad 14. Se også RAÅ, Landeværnets arkiv acc. 449/81. Lånet gik til købet af Løjt Sparekasses fordring. Beløbet endte med at blive $2.668 \mathrm{kr}$.

32. Se f.eks. Grv. 1937, s. 36 og 1938, s. 8 og 51.

33. NZ 20.10.1936.

34. RA $\AA$, Aabenraa politi nr. 280, rapport 28.5.1937.
35. Grv. 1937, s. 496. Jf. Holdt 1982, s. 53.

36. Nordslesvig venter nr. 11, december 1936.

37. RÅ, Aabenraa politi nr. 280, rapporter af 20., 21., 22. og 28.10. samt 2.11.1936.

38. NZ 21.10.1936.

39. NZ 22.10.1936.

40. NZ 23. og 24.10.1936.

41. Se f.eks. Jydske Tidende og Hejmdal 22.10.1936.

42. RAA, Kreditanstalt Vogelgesang nr. 1340, Schmidt til Vogelgesang 24.10.1936, Vogelgesang til Schmidt 29.10.1936, Vogelgesang til Ohrt 9.11.1936. Schmidt ytrede sig også kritisk i et brev til Karl Alnor 5.3. 1938, se Tägil 1970, s. 95.

43. RAA, Aabenraa politi nr. 280, rapport 2.11.1936, med fortsættelser til 13.11.1936.

44. Det følgende bygger på RA $\AA$, Retten i Aabenraa nr. 862, s. 257-269, medmindre andre kilder nævnes.

45. Luther 1981, s. 110.

46. Sst., s. 109.

47. Hejmdal 19.1.1937.

48. Rigsdagstidende. Forhandlinger i Folketinget 1936/37, bind III, sp. 6915f.

49. Frandsen 2002 , s. 217-219.

50. RA $\AA$, Aabenraa politi nr. 280, rapport af 1.11.1937.

51. Beretninger bl.a. i NZ 25. og 26.2., Jydske Tidende 27.2., Hejmdal 8.3. 1937.

52. RAA, Aabenraa politi nr. 280, rapport af 18.7.1937 med vedlagt trusselsbrev.

53. NZ 13.5.1936, her oversat efter Grv. 1937 s. $239 f$.

54. RAÅ, Retten i Aabenraa nr. 862, s. 257-269, jf. Grv. 1937, s. 238-243.

55. Se herom Grv. 1937, s. 258-262.

56. Citeret efter Grv. 1937 s. $242 f$.

57. Grv. 1937, s. 284.

58. Udskrift af Vestre Landsrets dom 22.7.1937 i RAA, Aabenraa politi nr. 280. Grv. 1937, s. 352-354.

59. Se herom Grv. 1937, s. 384f.

60. Udskrift af Højesterets dom 18.2. 1938 i RAA, Aabenraa politi nr. 280.

61. RAA, Politiadjudantens arkiv nr. 276, beretning for 1938 s. 13 .

62. RAA, Aabenraa politi nr. 280, rapport 13.12.1937. 
63. RAÅ, Retten i Aabenraa nr. 863, dom 25.10.1939. Jf. Grv. 1939, s. 489.

64. RAÅ, Aabenraa politi nr. 280, udskrift af dom 8.2.1940. Jf. Grv. 1940, s. $94 \mathrm{f}$.

65. Hejmdal 24.10.1936.

66. NZ 12.14.1937.

67. Grv. 1937, s. 448. RA $\AA$, Stollig andelsmejeris arkiv nr. 447/4, protokol 22.10.1937.

68. Sst. 13.6.1939.

69. Sst. 23.6., 30.6. og 10.7.1939.

70. RAÅ, Retten i Aabenraa nr. 363, her også udskrift af Vestre Landsrets dom.

71. Om flyvebladsaffæren, se RAA, Retten i Aabenraa nr. 862, s. 377-399. Et eksemplar af flyvebladet befinder sig i RAÅ, Politiadjudantens arkiv nr. 186.

72. Lovtidende 1930, s. 713. Straffeloven af 1930 § 78, stk. 1 .

73. Frandsen 2002, s. 223.

74. Tägil 1970, s. 96. Lenzing 1973, s. $128 \mathrm{f}$.

75. Frandsen 2002, s. 223.

76. NZ 8.12.1937.

77. NZ 9., 10., 11., 13., 14., 16. og 17.12. 1937.

78. Tägil 1970, s. $96 f$.
79. Udskrift af Vestre Landsrets dom i RAA, Det tyske mindretals arkiver nr. 1134

80. Grv. 1938 , s. 274,1939 , s. 15,31 f.

81. Tägil 1970, s. 97.

82. Se herom Frandsen 2002, s. 224 f.

83. Grv. 1938, s. 88-90 og 126-130.

84. RAA, Politiadjudantens arkiv nr. 186.

85. Se herom RAA, Retten i Aabenraa nr. 863, s. 56-74.

86. RAÄ, Retten i Aabenraa nr. 354.

87. Hejmdal 16.11.1937, svarende til Jydske Tidende 17.11.1937. Hejmdal fastholdt referatet. Peter Larsen fremkom ikke med indvendinger herimod. Citat efter Grv. 1937, s. 498-501.

88. RAA, politiadjudantens arkiv nr. 191, Schmidt til justitsministeren 19.6.1940.

89. Levinsen var dommer i Aabenraa frem til 1953, se Kraks Blå Bog 1955, s. 962.

90. Larsen 2014 , s. 62-70.

91. Se om Schmidt, Møller, Larsen og Christensen i Schultz Hansen 2014, især s. 317f, 321f, 328.

92. RAA, Retten i Aabenraa, tinglysningen, nr. 689.

93. JydskeVestkysten 20.3.2013.

\section{Zusammenfassung}

Im Jahr 1936 wurde ein Hof in Stollig nördlich von Apenrade zwangsversteigert. Der deutschgesinnte Eigentümer musste seinen Besitz an einen Dänisch gesinnten abgeben. Der Wechsel des Eigentümers wurde zu einem Teil des derzeitigen nationalen Kampfes um den Besitz. Dieses Verhältnis führte zu starken Reaktionen, die von leitenden Mitgliedern der nationalsozialistischen Kreise der deutschen Minderheit gefördert wurden. Verschiedene Methoden wurden benutzt, um den neuen Eigentümer vom Hof zu zwingen: Anonyme Diffamierung und Einschüchterung, Wandalismus an Haus, Brunnen und Maschinen, wirtschaftlicher Boykott und eigentliche Gewalttätigkeiten. Polizei, Anklagebehörde und Gerichtshof versuchten die Schuldigen zu finden, die Beweise führten aber nur zu einzelnen Verurteilungen. Der dänische Besitzer wurde nicht vom Hof vertrieben. Von Stollig verbreitete sich der Konflikt zu Zusammenstößen zwischen führen- 
den Nationalsozialisten aus der deutschen Minderheit und der dänischen Justizbehörde, die sich in den Gerichtssälen abspielten. Hier wurde eine heftig formulierte Kritik an den Behörden zurückgewiesen. Auf ihrem Höhepunkt berührte die «Stolligaffäre» große Teile der deutschen und dänischen Presse und des dänischen und deutschen Außenministeriums. Die moralische Verantwortung für die Konfrontationen lag bei hervortretenden deutschgesinnten Nationalsozialisten, die Handhabung von Seiten der dänischen Behörden fand aber nicht ohne innere Gegensätze statt, war aber aus übergeordneter Sicht durch rechtsstaatliche Normen gekennzeichnet. 